\title{
Sedimentary talc in Neoproterozoic carbonate successions
}

\section{Citation}

Tosca, Nicholas J., Francis A. Macdonald, Justin V. Strauss, David T. Johnston, and Andrew H. Knoll. 2011. "Sedimentary Talc in Neoproterozoic Carbonate Successions." Earth and Planetary Science Letters 306, no. 1-2: 11-22.

\section{Published Version}

doi:10.1016/j.epsl.2011.03.041

\section{Permanent link}

http://nrs.harvard.edu/urn-3:HUL.InstRepos:13041345

\section{Terms of Use}

This article was downloaded from Harvard University's DASH repository, and is made available under the terms and conditions applicable to Open Access Policy Articles, as set forth at http:// nrs.harvard.edu/urn-3:HUL.InstRepos:dash.current.terms-of-use\#OAP

\section{Share Your Story}

The Harvard community has made this article openly available.

Please share how this access benefits you. Submit a story.

\section{Accessibility}




\title{
Sedimentary talc in Neoproterozoic carbonate successions
}

\author{
Nicholas J. Tosca ${ }^{{ }^{*}}$, Francis A. Macdonald ${ }^{2}$, Justin V. Strauss ${ }^{2}$, David T. Johnston ${ }^{2}$, \\ Andrew H. Knoll ${ }^{2,3}$ \\ ${ }^{1}$ Department of Earth Sciences, University of Cambridge, Cambridge, CB2 3EQ, UK \\ ${ }^{2}$ Department of Earth and Planetary Sciences, Harvard University, Cambridge, MA 02138, USA \\ ${ }^{3}$ Department of Organismic \& Evolutionary Biology, Harvard University, Cambridge, MA \\ 02138, USA \\ *Corresponding author: njt41@,cam.ac.uk; T: +44 (0)1223 333442; F: +44 (0)1223 333450
}

\section{Abstract}

Mineralogical, petrographic and sedimentological observations document early diagenetic talc in carbonate-dominated successions deposited on two early Neoproterozoic ( 800-700 million years old) platform margins. In the Akademikerbreen Group, Svalbard, talc occurs as nodules that pre-date microspar cements that fill molar tooth structures and primary porosity in stromatolitic carbonates. In the upper Fifteenmile Group of the Ogilvie Mountains, NW Canada, the talc is present as nodules, coated grains, rip-up clasts and massive beds that are several meters thick. To gain insight into the chemistry required to form early diagenetic talc, we conducted precipitation experiments at $25^{\circ} \mathrm{C}$ with low- $\mathrm{SO}_{4}$ synthetic seawater solutions at varying $\mathrm{pH}, \mathrm{Mg}^{2+}$ and $\mathrm{SiO}_{2}$ (aq). Our experiments reveal a sharp and reproducible $\mathrm{pH}$ boundary (at $~ 8.7$ ) only above which does poorly crystalline $\mathrm{Mg}$-silicate precipitate; increasing $\mathrm{Mg}^{2+}$ and/or $\mathrm{SiO}_{2}(\mathrm{aq})$ alone is insufficient to produce the material. The strong $\mathrm{pH}$ control can be explained by Mg-silica complexing activated by the deprotonation of silicic acid above $~ 8.6-8.7$. FT-IR, TEM and XRD of the synthetic precipitates reveal a talc-like 2:1 trioctahedral structure with short-range stacking order. Hydrothermal experiments simulating burial diagenesis show that dehydration of the precipitate drives a transition to kerolite (hydrated talc) and eventually to talc. This formation pathway imparts extensive layer stacking disorder to the synthetic talc endproduct that is identical to Neoproterozoic occurrences. Early diagenetic talc in Neoproterozoic 
30 carbonate platform successions appears to reflect a unique combination of low $\mathrm{Al}$ concentrations

31 (and, by inference, low siliciclastic input), near modern marine salinity and $\mathrm{Mg}^{2+}$, elevated

$32 \mathrm{SiO}_{2}$ (aq), and $\mathrm{pH}>\sim 8.7$. Because the talc occurs in close association with microbially

33 influenced sediments, we suggest that soluble species requirements were most easily met through

34 microbial influences on pore water chemistry, specifically $\mathrm{pH}$ and alkalinity increases driven by 35 anaerobic Fe respiration.

37 Keywords: Proterozoic; geobiology; mineralogy; geochemistry; carbonate; silica

\section{Introduction}

Talc, $\mathrm{Mg}_{3} \mathrm{Si}_{4} \mathrm{O}_{10}(\mathrm{OH})_{2}$, is typically interpreted as a high-temperature mineral that forms

41 from hydrothermal alteration or metamorphism of Mg-rich and ultrabasic rocks (Evans and

42 Guggenheim, 1988; Marumo and Hattori, 1999). Lower temperature reactions can also produce

43 talc-bearing assemblages, for example through the weathering of serpentinite deposits (Velde

44 and Meunier, 2008); however, this class of reactions is far less common than its high temperature

45 counterpart. As such, outside of the scattered reports of talc in evaporite or carbonate rich 46 deposits (Bodine, 1983; Braitsch, 1971; Calvo et al., 1999; Friedman, 1965; Millot and Palausi,

47 1959; Noack et al., 1989), talc is rarely reported as a sedimentary mineral. Here we document the

48 unusual occurrence of early diagenetic talc associated with Neoproterozoic ( $\sim 800-700 \mathrm{Ma})$

49 carbonates deposited on two separate platform margins: the Akademikerbreen Group in Svalbard

50 and the Fifteenmile Group in the Ogilvie Mountains of northwestern Canada. The formation of

51 sedimentary talc and its mineralogical precursors requires a specific set of chemical conditions; 
52 its presence places tight quantitative constraints on Neoproterozoic ocean chemistry and provides

53 additional insight into the biogeochemistry of marine sediments at that time.

At low temperatures (i.e., less than $\sim 30^{\circ} \mathrm{C}$ ), the $\mathrm{Mg}$-silicate system is controlled mainly

55 by kinetic phenomena (Evans and Guggenheim, 1988; Jones, 1986; Wollast et al., 1968), and so

56 constraints on early diagenetic chemistry are difficult to derive based on thermodynamics alone.

57 To address this problem, we designed a series of experiments to evaluate the effects of changing

$58 \mathrm{pH}, \mathrm{Mg}^{2+}$ and $\mathrm{SiO}_{2}$ (aq) on the formation of $\mathrm{Mg}$-silicates from low-SO $\mathrm{SO}_{4}(\sim 2.8 \mathrm{mmol} / \mathrm{kg})$,

59 Neoproterozoic-like seawater solutions. When these experiments and companion modeling

60 results are coupled with stratigraphically constrained geochemical data, we are able to posit that

61 the early diagenetic talc in Neoproterozoic carbonate successions reflects a unique combination

62 of low siliciclastic input, near marine salinity and $\mathrm{Mg}^{2+}$, elevated $\mathrm{SiO}_{2}(\mathrm{aq})$, and $\mathrm{pH}$ greater than

63 8.6-8.7. In what follows, we discuss: (1) the sedimentology, geochemistry and mineralogy of

64 the Akademikerbreen and Fifteenmile talc occurrences, (2) experimental constraints on Mg-

65 silicate formation from modified Neoproterozoic-like seawater solutions, and (3) reports of

66 similar mineral assemblages from other Neoproterozoic successions. Finally, we consider both

67 the specific constraints these data place on the chemistry of waters bathing Neoproterozoic

68 carbonate platforms and why this interval in Earth history may have favored sedimentary talc

69 formation.

\section{2. Geologic Setting}

72 Sedimentary talc occurs in Neoproterozoic strata that crop out discontinuously over a

73 distance of more than $140 \mathrm{~km}$ in the Coal Creek and Hart River inliers of the Ogilvie Mountains,

74 Yukon (for exact locations see Macdonald and Roots, 2009). The talc is stratigraphically 
75 confined to the lower Callison Lake Dolostone (unit PF2 of the Fifteenmile Group), which 76 consists predominantly of dolomite with interbedded shale (Fig. 1 \& 2) (Macdonald and Roots, 77 2009; Macdonald et al., 2010). A tuff within the lowermost map unit of the Fifteenmile Group 78 provides a maximum age constraint on the talc of $811.51 \pm 0.25 \mathrm{Ma}$; a minimum constraint 79 comes from a $717.43 \pm 0.14$ Ma quartz-phyric rhyolite flow in the overlying Mount Harper 80 volcanic complex (Macdonald et al., 2010).

81 On a ridge $\sim 10 \mathrm{~km}$ to the northwest of Mt. Harper, the lower Callison Lake Dolostone is 82 well exposed and measures $77 \mathrm{~m}$ thick (Macdonald and Roots, 2009). Here, these strata rest 83 unconformably on a brecciated surface of PF1 platformal carbonate and consist of a basal $2 \mathrm{~m}$ of 84 channelized, sub-rounded quartz gravel conglomerate. These beds are overlain by $17 \mathrm{~m}$ of green 85 and red shale and siltstone with dolomite lenses containing microbialite textures. The 86 microbialite is draped with a $\sim 10 \mathrm{~cm}$ thick bed of hematite iron formation. Above the varicolored 87 shale and siltstone are an additional $60 \mathrm{~m}$ of black shale with laterally discontinuous dolomitic 88 bioherms and abundant microbialite. However, the black shale has a peculiar waxy luster, 89 reminiscent of phosphorite, and XRD analyses indicate that this shale consists almost exclusively

90 of talc. The black talc-bearing shale also contains lenses of redeposited talc rip-up clasts 91 suspended in fine-grained dolomite matrix and abundant black chert nodules. These strata are 92 succeeded gradationally by over $300 \mathrm{~m}$ of silicified dolostone (Unit PF3), dominated by 93 stromatolites, microbialaminite, and edgewise conglomerate with $\mathrm{cm}$-sized coated grains, 94 occasional exposure surfaces, and patchy silicification. These facies all suggest deposition in a 95 shallow-water, episodically exposed, marginal marine environment.

96 The talc is stratigraphically confined and laterally persistent along the outcrop belt for 97 over $30 \mathrm{~km}$ to the east to Mt. Gibben, and occurs again an additional $\sim 110 \mathrm{~km}$ to the east in the 
98 Hart River inlier (Abbott, 1997). This lateral extent suggests that talc deposition was at least a

99 basin-wide phenomenon. The Fifteenmile Group has been correlated with the Little Dal Group in

100 the Mackenzie Mountains (Macdonald et al., 2010), which has been interpreted as a marginal

101 marine carbonate bank deposited on a rifted passive margin (Turner and Long, 2008). However,

102 the significant unconformity recently identified at the base of the Callison Lake Dolostone

103 suggests that it may have formed in an additional distinct basin-forming episode (Macdonald and

104 Roots, 2009), perhaps coeval with the Coates Lake Group, which lies stratigraphically above the

105 Little Dal Group. The Coates Lake Group was deposited in narrow, restricted grabens (Jefferson

106 and Parrish, 1989). Although neither evaporitic minerals or pseudomorphs have been identified

107 in the Fifteenmile Group, evaporites are present in both the Little Dal and Coates Lake groups

108 (Jefferson and Parrish, 1989), and we cannot rule out restriction on the platform.

109 In Svalbard, $\mathrm{mm}$ to $\mathrm{cm}$ scale talc nodules occur within shallow marine carbonates of the

110 Hunnberg Formation, Nordaustlandet, and its lateral equivalents in Spitsbergen, the upper

111 Grusdievbreen and Svanbergfjellet formations (Fig. 2 \& 3; Knoll and Swett, 1990). As in

112 Canada, the talc deposits occur in settings ranging from coastal to subtidal environments below

113 storm wave base and can be traced along strike for several hundred kilometers, suggesting a

114 basin-scale phenomenon. Also as observed in Canada, $\mathrm{cm}$-scale hematite layers drape microbial

115 dolomites in the talc-bearing interval. In the Svanbergfjellet Formation, talc forms $\mathrm{cm}$-scale 116 nodules within relatively deep carbonaceous shales and carbonates. More extensive and striking,

117 however, are rounded nodules that formed within molar tooth structures and primary voids in

118 microbialites, in both cases before penecontemporaneous void-filling microspar cements were

119 deposited (Fig. 3; Knoll, 1984, who mistakenly identified the talc nodules as phosphorite). 
121 and Sr isotopic chemostratigraphy and biostratigraphy suggest an age broadly comparable to that

122 of the Ogilvie succession (Halverson et al., 2007; Knoll et al., 1986; Macdonald et al., 2010).

\section{3. Analytical and experimental methods}

125 Our sample suite was selected from the lower Callison Lake Dolostone of the Fifteenmile 126 Group and from throughout the Akademikerbreen Group (Fig. 2; Table 1). The Fifteenmile 127 Group samples, all from outcrop, include dolostone hosting nodular talc, bedded talc deposits, 128 and a small horizon of iron formation. With the exception of some visible surface staining, late 129 stage alteration/oxidation of the samples generally appears minor. Samples from the 130 Akademikerbreen Group are predominantly from the Svanbergfjellet Formation and correlative

131 horizons in the Hunnberg Formation, where nodular talc was identified in the field, but they also 132 include carbonates and shales from units above and below this interval. All Svalbard samples 133 were collected from outcrop and were chosen to capture the range of carbonate lithofacies 134 reported in Knoll and Swett (1990). Again, late stage alteration/oxidation is minor in Svalbard 135 samples, as documented by geochemical screens (e.g., $\mathrm{Sr}$ concentration, $\mathrm{Mn} / \mathrm{Sr}, \mathrm{Sr} / \mathrm{Ca}$ and $\delta^{18} \mathrm{O}$; 136 Derry et al., 1989).

137 Mineralogical analyses included X-ray diffraction (XRD) of $<2 \mu \mathrm{m}$ (and in some cases, $138<0.2 \mu \mathrm{m})$ oriented aggregates from decarbonated samples, and bulk XRD of unfractionated 139 samples. Petrographic analysis and electron microprobe analysis of selected samples were 140 performed using polished, carbon-coated thin sections. Further details of sample preparation and 141 analysis are given in the Supplementary file. 
143 synthetic low- $\mathrm{SO}_{4}$ seawater at various $\mathrm{Mg}^{2+}(\mathrm{aq})$ concentrations and $\mathrm{pH}$. Experiments were run in 144 water baths at $25 \pm 0.1{ }^{\circ} \mathrm{C}$ for a minimum of $4-5$ weeks to a maximum of 7 months, depending on 145 conditions. Filtered aqueous samples were collected periodically and analyzed by ICP-AES, and 146 residual solid precipitates were collected at experiment termination, washed and analyzed by

147 XRD, FT-IR and TEM. Selected solid precipitates were extracted and reacted with deionized 148 water at $180^{\circ} \mathrm{C}$ and $400^{\circ} \mathrm{C}$ to evaluate mineralogical changes in response to heating/dehydration. 149 Further details of the experimental and analytical procedures are given in the Supplementary file.

\section{4. Mineralogy and petrography of Neoproterozoic talc}

152 4.1 Fifteenmile Group

153 Nodular talc samples from the Callison Lake Dolostone have three components in 154 varying proportions: dolomite, chert, and talc. Detrital siliciclastic input is apparent only in the 155 lower $40 \mathrm{~m}$ of varicolored shale and siltstone with interbedded microbial dolomite (Fig. 2). The 156 thin horizon $(\sim 10 \mathrm{~cm})$ of iron formation that drapes the microbialite is mineralogically simple, 157 consisting of euhedral hematite grains dispersed in a dolomite matrix, with minor silicification 158 and rare detrital quartz grains. $<2 \mu \mathrm{m}$ size fractions reveal a single $7 \AA$ kaolin-serpentine group 159 phase with trioctahedral occupancy, consistent with greenalite. The dolomite is present both as 160 primary microbial laminations, coated grains, and as interstitial microspar cement. Talc both 161 drapes and fills laminae within the microbialites and, along with the black chert, forms early 162 diagenetic nodules. Bedded chert is also common. In silicified dolostones of the Callison Lake 163 Dolostone that host nodular talc, carbonate mineralogy consists exclusively of dolomite, with no

164 calcite indicated from powder XRD. Aside from talc, the clay mineralogy of decarbonated 
165 samples indicates lesser amounts of either discrete highly crystalline illite and/or mixed layer

166 illite/smectite. The composition of the mixed layer phases is highly consistent from sample to

167 sample, and analyses after ethylene glycol treatment are consistent with R0 (disordered)

168 illite(0.7)/smectite.

169 The bedded talc horizons consist predominantly of black, talc-rich shale. Thin lenses of

170 sub-angular to sub-rounded rip-up clasts of talc supported by very fine-grained dolomite matrix

171 are interbedded with the talc horizons. The interstitial dolomite cements between the reworked

172 talc clasts suggest that at least some of the talc formation predates the formation of these

173 particular cements. The mineralogy of bedded talc samples is also simple; talc overwhelms bulk

174 analyses and clay fractions in abundance. However, two samples of bedded talc revealed

175 subordinate amounts of discrete highly crystalline illite and mixed layer R0 illite $(0.7) /$ smectite

176 (Table 1). In contrast to bulk samples, oriented $<2 \mu \mathrm{m}$ size fractions of bedded talc indicate that

177 no mixed layering is apparent. In other words, the talc is present as a discrete mineral phase. No

178 other Mg-silicates were identified in any bulk or $<2 \mu \mathrm{m}$ fractions from Fifteenmile Group

179 samples (Fig. 4). Randomly oriented specimens of the $<2 \mu \mathrm{m}$ clay fraction further indicate that

180 the talc exhibits a high degree of stacking disorder; it is essentially turbostratic. A number of $h k l$

181 peaks are significantly modulated, particularly in the 20-25 degree and 30-45 degree range. This

182 type and extent of disordering is present in all of the Fifteenmile talc occurrences.

183 The carbonate overlying the talc horizons consists of silicified dolomite with microbial

184 lamination, coated grains, and abundant stromatolites. Void-filling cements consist

185 predominantly of dolomite and silica. Decarbonated samples from these strata also yielded talc

186 with lesser amounts of discrete illite and mixed layered illite/smectite. The talc in these samples 
187 is distributed throughout the carbonate matrix and not as nodules or other conspicuous 188 sedimentary features otherwise resolvable by petrographic analysis.

\subsection{Akademikerbreen Group}

Akademikerbreen talc occurs as $\mathrm{mm}$ - to $\mathrm{cm}$-scale nodules and disseminated particles in

192 the $<2 \mu \mathrm{m}$ fraction of the carbonate matrix. Talc nodules fill molar tooth structures, primary void 193 space in microbialites and intergranular space, predating precipitation of penecontemporaneous

194 microspar cement. In general, nodules are petrologically homogeneous; there are no discernable 195 nuclei nor is chemical zoning evident (Fig. 3).

196 Powder XRD of isolated and cleaned nodules hand picked from Akademikerbreen 197 carbonates shows the same type and extent of layer stacking disorder as in the Fifteenmile talc 198 samples (Fig. 5). That is, the Akademikerbreen talc is also highly turbostratic. XRD patterns 199 again display modulated and/or extinguished $h k l$ reflections in the $20-25$ and $30-45$ degree $2 \Theta$ 200 ranges. Aside from talc, the carbonate mineralogy frequently includes ankerite in addition to 201 dolomite and lesser amounts of calcite.

202 The clay mineralogy of decarbonated Akademikerbreen samples shows more variation 203 among the Mg-silicates. Analyses of decarbonated residues reveal talc in the carbonate matrix in 204 some samples where nodules are not apparent. The talc again shows no evidence of mixed 205 layering or occurrences with other low temperature Mg-silicates such as sepiolite or palygorskite. 206 However, saponite (a Mg-rich trioctahedral smectite) and its burial diagenetic equivalents, mixed 207 layered chlorite/smectite and corrensite, have all been identified (Fig. 4; Table 1; Supplementary 208 file). 
In addition to Mg-silicates, Akademikerbreen clay fractions contain varying amounts of

210 discrete highly crystalline illite, illite/smectite (most of which corresponds to R1

211 illite(0.7)/smectite), kaolinite, and, in one sample only, chlorite. In general, the results

212 summarized in Table 1 show that samples containing talc and other associated $\mathrm{Mg}$-silicates

213 consistently lack illite, I/S, and kaolinite. The reverse is also true: aluminous clay mineral

214 assemblages are rarely accompanied by talc.

215 The Svanbergfjellet, Draken and Backlundtoppen Formations also contain discrete 216 siliciclastic horizons that represent detrital pulses into the carbonate platform (Butterfield et al.,

217 1994; Knoll and Swett, 1990). The clay mineralogy of these horizons is dominated by illite and

218 kaolinite in the $<2 \mu \mathrm{m}$ fraction; the $<0.2 \mu \mathrm{m}$ fraction is composed almost entirely of discrete illite,

219 with significant defect broadening.

2214.3 Fifteenmile and Akademikerbreen Group Mg-silicate occurrences: Summary

222 Sedimentology and petrology indicate that talc formed during early diagenesis, perhaps

223 penecontemporaneously, in both the Akademikerbreen and the Fifteenmile Groups. In both

224 environments the clay mineralogy also indicates that talc generally occurs in environments that

225 received low background siliciclastic flux, and where alumino-silicates are present, talc has not

226 been identified.

227 Saponite, chlorite/smectite and corrensite in Akademikerbreen carbonates, all indicate

228 that saponite formed during early diagenesis and was transformed to chlorite-rich mineral species

229 upon burial and late-stage alteration. Because there is little evidence for mafic input to the 230 Akademikerbreen platform, saponite formation suggests that the initial deposition of smectite 231 (originally as a dioctahedral smectite such as montmorillonite), or some other detrital precursor, 
232 initiated a recrystallization/transformation to trioctahedral saponite, likely in response to

233 favorable aqueous chemistry associated with the platformal carbonates (discussed below).

234 Samples from the Fifteenmile Group, on the other hand, yield very little decarbonated

235 residue and show little variation in background siliciclastic component; they are dominated by

236 highly crystalline illite (muscovite) and illite/smectite. Together this implies very low

237 background detrital fluxes and negligible input of terrigenous clay beyond detrital muscovite.

238 The sedimentology, petrography and mineralogy of these deposits are indicative of

239 unusual aqueous chemistry associated with platformal carbonates that facilitated the early

240 diagenetic precipitation of $\mathrm{Mg}$-silicates, whether talc or a precursor phase, from solution. What

241 drove these reactions during Akademikerbreen and Fifteenmile Group deposition?

\section{5. Constraints from Mg-silicate precipitation experiments}

244 To better understand what chemical environment is required to initiate the precipitation 245 of Mg-silicates, we performed a systematic series of experiments interrogating the role of $246 \mathrm{SiO}_{2}$ (aq) and $\mathrm{pH}$ on talc formation. We incubated one liter batches of standard, "modern" 247 synthetic seawater at various $\mathrm{SiO}_{2}(\mathrm{aq})$ concentrations and $\mathrm{pH}$, monitoring the bottles for both 248 precipitation of solid phases and changes in aqueous chemistry. In certain experiments, a visible 249 precipitate formed within the first 48 hours. The precipitate often clouded the solution before 250 flocculating and, eventually, settled to the bottom of the reaction vessel. In other experiments, no 251 precipitate was formed over $>7$ months.

252 When the experimental conditions favored precipitation, XRD analyses on randomly 253 oriented powders showed broad and poorly resolvable $h k l$ bands and no 001 reflections (Fig. 5).

254 All XRD analyses showed weak bands at $d=1.55$ to $1.52 \AA$, indicating the presence of 
255 trioctahedral layers, and all $h \mathrm{kl}$ bands were reproducible from experiment to experiment, 256 displaying little variation in their relative intensity and $d$-spacing. In only one case, the 257 experiment conducted at the highest $\mathrm{pH}$, a precipitate gave broad low-angle reflections 258 corresponding to $d$-spacings of 28.7, 13.9 and $10.4 \AA$. With the exception of the highest $\mathrm{pH}$ 259 experiment, the structure of the precipitate is both insoluble and reproducible from experiment to 260 experiment. Perhaps most striking, however, is the observation that the precipitate only formed at 261 a pH of 8.66 and above, implicating $\mathrm{pH}$ as a major control on $\mathrm{Mg}$-silicate precipitation.

263 experimental precipitates are almost identical to talc. The close correspondence between $\mathrm{Mg}-\mathrm{O}$

264 vibrations from the precipitates and lattice vibrations from talc (including the diagnostic $535 \mathrm{~cm}^{-}$

$265^{1}$ (Mg-O)-OH feature (Farmer, 1974; Zhang et al., 2006)) reflect a similar bonding environment 266 for $\mathrm{Mg}$ (Fig. 6). Absorptions at $\sim 1020 \mathrm{~cm}^{-1}$ show the same bonding arrangement for $\mathrm{SiO}_{4}$ 267 tetrahedra: a 2:1 layered configuration of tetrahedral silicate layers and octahedral $\mathrm{MgO}_{6}$ layers 268 (Fig. 6). A trioctahedral occupancy (consistent with XRD peaks at 1.55-1.52 Å), manifested by 269 the $\mathrm{OH}$-stretching vibration at $\sim 3676 \mathrm{~cm}^{-1}$, is also evident for both the precipitates and for talc 270 standards. However, the lack of an observable basal 001 reflection in oriented XRD patterns 271 suggests that there is little to no stacking order between TOT sheets, perhaps due to variable 272 interlayer/surface hydration (consistent with absorptions at $\sim 1630$ and $\sim 3400 \mathrm{~cm}^{-1}$ indicating 273 appreciable bound molecular $\mathrm{H}_{2} \mathrm{O}$ ). Taken together, XRD, FT-IR and TEM data (shown in the 274 Supplemental File) indicate the experimental precipitates are simply a hydrated, disordered form 275 of talc; they are composed of 2-dimensional talc TOT sheets not neatly stacked as in true talc, 276 but organized similar to a pile of bricks loosely cemented with water of hydration. 
To ascertain the effects of mild heating on poorly crystalline Mg-silicate precipitated

278 from modified seawater solutions, we also performed experiments involving the hydrothermal

279 treatment of poorly crystalline Mg-silicate (the products of precipitation experiments) in the 280 presence of deionized water. After 4 weeks of reaction at $180^{\circ} \mathrm{C}$, the poorly crystalline $\mathrm{Mg}$ -

281 silicate transformed to kerolite $\left(\mathrm{Mg}_{3} \mathrm{Si}_{4} \mathrm{O}_{10}(\mathrm{OH})_{2} \cdot n \mathrm{H}_{2} \mathrm{O}\right)$, a distinct mineral phase and hydrated

282 structural analog of talc (Fig. 5). The final product exhibited an apparent $d(001)$ of $9.9 \AA$ and $h k l$

283 peaks that correspond to the kerolite structure discussed in Brindley et al. (1977). Combined

284 XRD, FT-IR and TEM data indicate that simple dehydration -- in this case, in response to

285 temperature increase - drives the transformation from poorly crystalline $\mathrm{Mg}$-silicate to the

286 mineral kerolite. Further heating at elevated temperature or over long timescales in turn causes

287 additional dehydration and experiments conducted at $400^{\circ} \mathrm{C}$ and $1 \mathrm{kbar}$ show that this dehydration

288 drives the transition from kerolite to talc (and minor cristobalite) (Fig. 5). The talc produced

289 from this process exhibits significant turbostratic ordering and powder diffraction data show

290 similar peak modulation to Neoproterozoic talc samples discussed above.

292 6. Discussion

2936.1 Mg-silicate system at low temperature

294 Present-day seawater is supersaturated with respect to crystalline talc, yet modern and 295 even ancient environments lack authigenic talc (Fig. 7). Like in the case of carbonate 296 precipitation, there must exist a kinetic barrier to talc precipitation; a barrier that we can address 297 through experimental interrogation. Our data and ensuing discussion allow talc precipitation to 298 be reconstructed in an environmentally tuned, step-wise fashion. 
Previous experimental work has targeted talc precipitation from modern-like seawater,

300 and presents contrasting results to those described herein. Wollast et al. (1968) spiked filtered

301 modern seawater with sodium metasilicate $\left(\mathrm{Na}_{2} \mathrm{SiO}_{3}: 9 \mathrm{H}_{2} \mathrm{O}\right)$ at $25^{\circ} \mathrm{C}$ and precipitated a $\mathrm{Mg}-$

302 silicate phase at $\mathrm{pH}>8.3$. The Mg-silicate was described as "poorly crystalline sepiolite" on the

303 basis of FT-IR and XRD -- a phase not identified in any of our experiments. In addition, the

304 apparent solubility calculated from their experiments is lower than the experiments described

305 here (Fig. 7), implying a lower degree of supersaturation needed for precipitation. Upon closer

306 inspection, however, the Mg-silicate precipitated by Wollast et al. (1968) is not inconsistent with

307 our results. In fact, their FT-IR and XRD analyses also lack the most diagnostic features of

308 sepiolite, including the $12 \AA$ and $7.5 \AA$ diffraction peaks and a Si-O feature in FT-IR attributed to

$309 \mathrm{Q}_{3}$ bonding of silica tetrahedra in chain silicates (Russell and Fraser, 1994). However, their

310 material also appears to exhibit FT-IR features that ours does not.

311 Aside from the identity of the initial precipitate, there also remains a clear discrepancy in

312 the literature in the aqueous conditions needed to initiate precipitation. To address this, we

313 duplicated some of the experiments conducted by Wollast et al. (1968) using a synthetic

314 "modern" seawater solution at elevated $\mathrm{SiO}_{2}(\mathrm{aq})$. The only difference is the nature of the silica

315 source: TEOS solutions in experiments described here versus sodium metasilicate solutions in

316 Wollast et al. (1968). The results show that Mg-silicate formation does not occur until higher

317 levels of supersaturation than those reported by Wollast et al. (1968) and that the initial

318 precipitate is a known kerolite precursor. We argue that the difference in silica source may well

319 be critical. We have taken precautions to ensure that $\mathrm{SiO}_{2}(\mathrm{aq})$ added to seawater solutions was

320 equilibrated in the monomeric form prior to the addition of $\mathrm{MgCl}_{2}$ (Dietzel, 2000; Iler, 1979). In

321 contrast, sodium metasilicate solutions are known to polymerize rapidly and form colloidal 
322 material upon dilution (Iler, 1979), perhaps in response to decreasing silica levels and/or rapid

323 changes in $\mathrm{pH}$ associated with their preparation. Thus, it is possible that the addition of

324 metasilicate solutions to seawater solutions co-precipitated silica with $\mathrm{Mg}^{2+}$ in a way that may

325 not be truly representative of natural surface environments. This is a complication avoided in

326 our experiments through the use of TEOS as a $\mathrm{SiO}_{2}(\mathrm{aq})$ source.

\subsection{Mg-silicate formation: $\mathrm{pH}$ as a master variable}

329 To assess what special combination of $\mathrm{Mg}^{2+}, \mathrm{SiO}_{2}(\mathrm{aq})$ and $\mathrm{pH}$ results in $\mathrm{Mg}$-silicate 330 precipitation, we ran experiments varying $\mathrm{Mg}^{2+}$ concentrations (by 10 times over modern 331 seawater) and at variable $\mathrm{pH}$ (Fig. 7). As discussed above, raising $\mathrm{SiO}_{2}$ (aq) alone was 332 insufficient to drive precipitation. In fact, our experiments identify $\mathrm{pH}$ as the primary control on $333 \mathrm{Mg}$-silicate formation. At a $\mathrm{pH}_{\mathrm{f}}$ of 8.0, we observed no precipitation over the course of the

334 experiment. Within error, $\mathrm{SiO}_{2}(\mathrm{aq})$ levels remained unchanged for $>5$ months with no sign of 335 precipitation. In contrast, the same $\mathrm{Mg}^{2+}$ and $\mathrm{SiO}_{2}(\mathrm{aq})$ at elevated $\mathrm{pH}$ resulted in the rapid 336 precipitation of $\mathrm{Mg}$-silicate on the timescale of days, suggesting that despite exceedingly high $337 \mathrm{Mg}^{2+}$ levels, $\mathrm{pH}$ appears to be the primary control on Mg-silicate formation from seawater338 derived solutions.

339 Solution chemistry at experiment termination tells a similar story. Relationships between $340 \mathrm{SiO}_{2}$ (aq) loss and $\mathrm{pH}_{\mathrm{f}}$ reveal a sharp speciation boundary for $\mathrm{SiO}_{2}$ (aq) at $\sim 8.6-8.7$ (Fig. 8).

341 Below this threshold, $\mathrm{SiO}_{2}(\mathrm{aq})$ is unchanged within analytical error (compared to "blank" 342 experiments conducted in the absence of $\mathrm{MgCl}_{2}$ ). At $\mathrm{SiO}_{2}(\mathrm{aq})$ concentrations between 343 amorphous silica and quartz saturation, the dominant silica species in seawater is monomeric 344 silica; $\mathrm{H}_{4} \mathrm{SiO}_{4}{ }^{0}$. As $\mathrm{pH}$ is increased above $\sim 8.5, \mathrm{H}_{4} \mathrm{SiO}_{4}{ }^{0}$ deprotonates, favoring $\mathrm{H}_{3} \mathrm{SiO}_{4}{ }^{-}$(Fig. 9). 
345 As a result, at these higher $\mathrm{pH}$ values, the concentration of a $\mathrm{Mg}$-silica complex $\left(\mathrm{MgH}_{3} \mathrm{SiO}_{4}{ }^{+}\right)$

346 increases sharply. The $\mathrm{MgH}_{3} \mathrm{SiO}_{4}{ }^{+}$species alone is probably not representative of all possible

347 aqueous Mg-silica complexes in solution, especially given the complexity of silica speciation

348 revealed by NMR (Felmy et al., 2001). Nevertheless, the stability constant for this species

349 (derived from actual potentiometric measurements of $\mathrm{SiO}_{2}(\mathrm{aq})$ and $\mathrm{Mg}$-bearing solutions at

350 various $\mathrm{pH}$ and high salinity) shows that regardless of actual species distribution, the $\mathrm{pH}$

351 dependence of $\mathrm{Mg}$-silica complexing is well represented by $\mathrm{MgH}_{3} \mathrm{SiO}_{4}{ }^{+}$(Santschi and $\mathrm{Schindler}$, 352 1974).

353 It is possible that at low $\mathrm{pH}$, the rate of crystallization is too slow to be observed.

354 However, the idea of a minimum $\mathrm{pH}$ for $\mathrm{Mg}$-silicate formation is well supported by previous

355 synthesis experiments. For example, Siffert and Wey (1962), using dilute $\mathrm{MgCl}_{2}$ solutions and 356 monomeric $\mathrm{SiO}_{2}(\mathrm{aq})$, precipitated "true" sepiolite at $\mathrm{pH}>8.5$. At $\mathrm{pH}>9$, talc and stevensite 357 formed. Abtahi (1985) and La Iglesia (1978) obtained similar results. The same trends have been 358 observed by workers synthesizing "Mg-silicate hydrate" for industrial applications, with some 359 citing a canonical $\mathrm{pH}$ for "Mg-silicate scale" formation of $\sim 8.5$ (Brew and Glasser, 2005a; Brew 360 and Glasser, 2005b; Delacaillerie et al., 1995; Mizutani et al., 1990; Packter, 1986; Strese and 361 Hofmann, 1941; Takahashi et al., 1994; Wei and Chen, 2006).

$362 \mathrm{MgH}_{3} \mathrm{SiO}_{4}{ }^{+}$and similar species are, in turn, the solution precursors to $\mathrm{Mg}$-silicate 363 precipitates (Packter, 1986). Theoretical treatments of layer silicate nucleation from solution 364 require that an excess surface energy barrier be overcome by a critical supersaturation of a pre365 existing solution complex (Carrado et al., 2006). The critical supersaturation barrier to initiate 366 Mg-silicate formation, then, must occur close to $\mathrm{pH}$ 8.6-8.7. Below this point, speciation 367 calculations show that aqueous Mg-silicate complexes, while present, are unlikely to be 
368 concentrated enough to initiate the nucleation of a silicate phase; deprontonated silica species

369 would be kept to scant amounts in solution, preventing appreciable interaction with $\mathrm{Mg}^{2+}$. This

370 strong kinetic control on Mg-silicate precipitation from seawater is reminiscent of the more

371 familiar problem of $\mathrm{CaCO}_{3}$ precipitation from modern surface seawater. For both systems,

372 despite a clear thermodynamic driving force, a critical level of supersaturation is required. For

373 Mg-silicates, deprotonation of $\mathrm{H}_{4} \mathrm{SiO}_{4}{ }^{0}$ at elevated $\mathrm{pH}$ appears to be the "switch" that enables

374 Mg-silica complexing, in turn driving Mg-silicate nucleation and precipitation.

\subsection{Burial diagenesis and turbostratic stacking disorder in talc}

The sedimentary record of authigenic Mg-silicates can be related to solution chemistry

378 only with knowledge of thermal transformations possible during burial diagenesis. Our

379 hydrothermal experiments run with poorly crystalline Mg-silicates precipitated from seawater

380 show that upon dehydration, the material readily transforms to kerolite. Previous work has

381 shown that with continued dehydration, either with time or at increased temperature, kerolite, in

382 turn, transforms to crystalline disordered talc (Mitsuda and Taguchi, 1977). Our heating

383 experiments with kerolite confirm these observations and show that the talc formed by

384 dehydrating kerolite exhibits severe layer stacking disorder identical to the disorder observed in

385 Akademikerbreen and Fifteenmile samples (Fig. 5).

386 Stacking disorder in talc is not uncommon. In fact, it results from an inherently weak

387 electrostatic charge between 2:1 layers (Giese, 1975). The disorder observed in our samples is

388 best matched by ordered stacking of 2:1 layers by $a / 3$ along one of the pseudo-hexagonal axes,

389 with random displacements of $\pm b / 3$ along another (Gualtieri, 1999). It is not clear why this type

390 of disordering results, but as others have noted, it may well be controlled by the pathway of 
391 crystallization (in this case, dehydration) rather than solid state transformation (Baronnet, 1992;

392 Kogure and Kameda, 2008). Specifically, the 2:1 layer dehydration mechanism of the low

393 temperature precipitate, which initiates stacking to form kerolite and, in turn, talc, may well exert

394 the most control on the type of disorder that results from this pathway. Nevertheless, this poorly

395 understood feature is present in all Neoproterozoic samples, consistent with low temperature

396 precipitation and subsequent dehydration during burial.

397 Although there are no direct temperature constraints on the samples described herein,

398 Neoproterozoic strata in the Yukon are relatively low-grade for rocks of their age. Regionally,

399 conodont alteration indices and vitrinite reflectance from the overlying Paleozoic strata suggest

400 these rocks have not seen more than $140^{\circ} \mathrm{C}$ (Van Kooten et al., 1997). A similar thermal history

401 of the Svalbard samples is suggested by paleomagnetic studies in which demagnetization

402 experiments removed a Caledonian thermochemical remnant magnetization at $150^{\circ} \mathrm{C}$ (Maloof et

403 al., 2004). Moreover, the orange-brown color of preserved organic matter in the

404 Akademikerbreen Group indicates that the degree of graphitization and maximum burial

405 temperatures were modest. In reconciling these constraints with experimental data discussed

406 above, it is important to note that we have used elevated temperature (up to $400^{\circ} \mathrm{C}$ ) purely to

407 observe the dehydration of poorly crystalline Mg-silicate to kerolite and eventually to talc on

408 convenient laboratory timescales. However, this transition is known to occur in response to

409 lower temperature and longer reaction time (Mitsuda and Taguchi, 1977). Indeed, if the kinetics

410 of the Mg-silicate dehydration reaction were to behave in a similar fashion to other burial

411 diagenetic reactions involving clay minerals, the dehydration of poorly crystalline $\mathrm{Mg}$-silicate to

412 talc could, for example, take as little as $10^{5}$ years at $\sim 80^{\circ} \mathrm{C}$ (Velde, 1985).

413 
Taken together, experimental data indicate that low temperature talc formation in 416 association with carbonates requires: (1) elevated $\mathrm{SiO}_{2}(\mathrm{aq})$, between quartz and amorphous silica 417 saturation; (2) sufficient (at least "modern") $\mathrm{Mg}^{2+}$; (3) near marine salinity; (4) low $\mathrm{Al}$ (i.e., a 418 low background detrital flux, see below) and (5) elevated $\mathrm{pH}$ of at least $\sim 8.7$.

419 One key requirement for talc precipitation that we have yet to discuss is low $\mathrm{Al}$, requiring 420 that detrital fluxes were low during deposition of the talc-bearing intervals in the 421 Akademikerbreen and Fifteenmile groups. $\mathrm{As} \mathrm{Al}^{3+}$ increases in concentration, talc, a nominally 422 Al-free mineral, is no longer stable, being replaced instead by Al-bearing smectites, chlorites, 423 palygorskite or other minerals depending on local pore water chemistry and sediment supply 424 (Jones, 1986; Jones and Galan, 1988; Weaver and Beck, 1977). Low detrital fluxes have been 425 episodic features of carbonate platform environments throughout recorded Earth history, and 426 don't place a unique chemical constraint beyond that discussed. Thus, our mineralogical 427 observations of low siliciclastic flux in talc-bearing facies of the Akademikerbreen and 428 Fifteenmile successions helps to explain the distribution of early diagenetic talc in space but not 429 in time.

430 The requirement of elevated $\mathrm{SiO}_{2}(\mathrm{aq})$ concentration was also readily met in 431 Neoproterozoic seawater. Indeed, prior to the evolution of silica skeletons in sponges, 432 radiolarians and diatoms, Precambrian seawater should have carried higher silica concentrations 433 relative to modern levels (Maliva et al., 2005). Consistent with this expectation, early diagenetic 434 chert in Neoproterozoic carbonate successions, largely from peritidal or possibly mildly 435 evaporitic environments, provides evidence for local pore water enrichment in $\mathrm{SiO}_{2}(\mathrm{aq})$ on 436 shallow water platforms (Maliva et al., 2005). The Akademikerbreen Group abounds with 
437 evidence for early diagenetic silicification (e.g., Fairchild et al. 1991; Knoll, 1984; Knoll and 438 Swett, 1990). Fifteenmile Group samples are also heavily silicified, but record a more complex 439 history of silicification (Mustard and Donaldson, 1990).

440 The Akademikerbreen and Fifteenmile Groups were likely deposited on marginal to 441 isolated marine platforms (Knoll and Swett, 1990; Macdonald et al., 2010). Near marine salinity $442(\sim 35 \%)$ and $\mathrm{Mg}^{2+}$ concentrations are consistent with these settings, yet the salinity and $\mathrm{Mg}^{2+}$ 443 content of Proterozoic seawater is poorly constrained. Oolites in the Akademikerbreen Group 444 provide petrographic and geochemical (high Sr) evidence for an aragonite sea at the time of their 445 deposition, suggesting that contemporaneous seawater may have had $\mathrm{Mg}^{2+}$ concentrations 446 broadly similar to those observed today (Swett and Knoll, 1989). Although no evaporite minerals 447 or their associated pseudomorphs have been identified in either succession, episodic restriction in 448 the Akademikerbreen and Fifteenmile Groups cannot be ruled out. On the other hand, seawater 449 evaporation should decrease $\mathrm{pH}$ (e.g., McCaffrey et al., 1987), which is inconsistent with the 450 stability of talc.

451 Talc formation by meteoric mixing faces a similar constraint, as freshwater influx would 452 tend to drive $\mathrm{pH}$ below marine values. Additionally, salinity would further decrease in response 453 to post-depositional meteoric influx. Higher water activity (or lower salinity) favors the 454 precipitation of Mg-silicates of higher hydration, namely sepiolite. Lower water activity (or near 455 normal marine salinity), on the other hand, favors kerolite and/or other 2:1 silicates, and 456 synthesis work reinforces these constraints (Jones and Galan, 1988; Siffert and Wey, 1962; 457 Stoessell and Hay, 1978). Mg-silicate occurrences in peri-marine and lacustrine environments 458 also conform to this trend, so well, in fact, that Mg-silicate assemblages have been used to track 459 salinity fluctuations and the influence of meteoric water in a number of modern and ancient 
460 settings (Calvo et al., 1999; Jones, 1986; Stoessell and Hay, 1978; Weaver and Beck, 1977;

461 Webster and Jones, 1994).

462 Of all the requirements for early diagenetic talc formation, elevated $\mathrm{pH}(\geq \sim 8.7)$ is the 463 most problematic, given the difficulty of increasing seawater $\mathrm{pH}$, which is largely buffered by 464 the carbon cycle, to the required level. The more realistic alternative is to increase $\mathrm{pH}$ in pore 465 waters via microbial processes. Elevated $\mathrm{pH}$ can be achieved through certain microbial reactions 466 that remineralize organic matter, a set of processes that need not have decreased salinity, $\mathrm{Mg}^{2+}$ 467 and/or $\mathrm{SiO}_{2}(\mathrm{aq})$ levels. Both the Akademikerbreen and Fifteenmile talc deposits are intimately 468 associated with microbial facies: bedded talc drapes occur with microbialaminites and 469 stromatolites in Fifteenmile samples, and both localities host talc nodules within microbialites.

470 Anaerobic respiration is a particularly attractive mechanism for increasing $\mathrm{pH}$. In a 471 Neoproterozoic world with low $\mathrm{pO}_{2}$ and no macrometazoan bioturbation, anoxia would have 472 been a common feature of early diagenetic carbonate sediments. Given the additional likelihood 473 that nitrate levels were also low (Fennel et al., 2005), ferric iron and sulfate would have been the 474 most energetically favorable oxidants available for organic carbon remineralization, with $\mathrm{Fe}^{3+}$ 475 favored over $\mathrm{SO}_{4}{ }^{2-}$ (Canfield et al., 2005). Under conditions where the reactive Fe flux was high, 476 (perhaps ultimately sourced from hydrothermal Fe fluxes rather than detrital input in these 477 sediment-starved environments) dissimilatory $\mathrm{Fe}$ reduction would have been particularly 478 effective at increasing $\mathrm{pH}$ through the following reaction:

$$
2 \mathrm{CH}_{2} \mathrm{O}+8 \mathrm{Fe}(\mathrm{OH})_{3} \rightarrow 2 \mathrm{CO}_{2}+8 \mathrm{Fe}^{2+}+6 \mathrm{H}_{2} \mathrm{O}+16 \mathrm{OH}^{-}
$$

480 When the reactive $\mathrm{Fe}$ pool was kept low, either by exhaustion of reactive $\mathrm{Fe}^{3+}$ or by pyrite 481 precipitation (Johnston et al., 2010; Lyons and Severmann, 2006), sulfate reduction would have 482 contributed to a $\mathrm{pH}$ increase in solution: 
484 Fe-speciation and isotopic analyses of other early Neoproterozoic successions indicate that these 485 two metabolic pathways strongly influenced marine chemistry in both basinal and platform 486 settings, with organic carbon fluxes and variations in basinal $\mathrm{Fe}$ and $\mathrm{S}$ cycles controlling the 487 balance between them (Canfield et al., 2008; Johnston et al., 2010; Johnston et al., 2009). But 488 regardless of the interplay between different types of anaerobic respiration, both pathways would 489 have resulted in a pH increase without changes in other conditions needed for talc precipitation. 490 Pore waters in microbially-dominated sediments would have been especially susceptible to $\mathrm{pH}$ 491 increase driven by anaerobic respiration, where higher sediment to pore-water ratios favored 492 more effective changes in chemistry

493 In addition to the Svalbard and Canadian occurrences described here, sedimentary (oolitic) 494 talc has been reported in association with stromatolitic dolomites in an Infracambrian 495 (Neoproterzoic) succession of the Volta Basin of West Africa (Millot and Palausi, 1959). The 496 authors argue from petrographic analyses that talc formation preceded dolomitization and 497 silicification. Noack et al. (1989) also reported oolitic talc in the Schisto-Calcaire Group of the 498 West Congo Basin. Overlying the Upper Diamictite Formation, Schisto-Calcaire carbonates have 499 strontium isotope values of 0.7073 (Frimmel et al., 2006; Poidevin, 2007), consistent with a 500 Cryogenian age (716-635 Ma). The sedimentology of the Schisto-Calcaire Group has been 501 interpreted to reflect alternately shallow marine and lagoonal conditions, separated from outer 502 subtidal regions of the platform by stromatolitic reefs (Trompette and Boudzoumou, 1988). 503 Noack et al. (1989) interpret the talc to have formed by transformation from stevensite or 504 sepiolite on the basis of thermodynamic considerations. This interpretation is not incompatible 505 with ours; stevensite precipitation is generally only observed from synthesis studies at high $\mathrm{pH}$ 
506 and near marine salinity (La Iglesia, 1978; Siffert and Wey, 1962). We have not conclusively

507 identified stevensite in our experiments, but have identified a corrensite-like phase forming with

508 talc at high $\mathrm{pH}$. Corrensite formation at low temperature requires the initial formation of a

509 stevensite-like smectite into which brucite-like layers are precipitated (Reynolds, 1988).

510 The apparent concentration of low temperature talc deposits in mid-Neoproterozic

511 carbonate platforms may find explanation in the superposition of Neoproterozoic-specific

512 environmental conditions on the broader set of requirements (low detrital influx, high silica, low

513 oxygen, sufficient $\mathrm{Mg}$, efficient sulfide scavenging (Ben-Yaakov, 1973)) likely to have

514 characterized Precambrian carbonate platforms in general. Fe speciation chemistry indicates that

515 iron played a more important role in organic remineralization after 800 million years ago than it

516 did earlier in the Proterozoic Eon (Canfield et al., 2008; Johnston et al., 2010). Also, the

517 hypothesized shift from a Mesoproterozoic biosphere with warm, high $\mathrm{pCO}_{2}$ atmosphere with

518 high seawater DIC to a more glacial-prone later Neoproterozoic world with lower $\mathrm{pCO}_{2}$ and DIC

519 would further have eased chemical resistance to increases in pore-water $\mathrm{pH}$ in Neoproterozoic

520 carbonate platforms (Kah and Bartley, 2004). During deposition of the Akademikerbreen and

521 Fifteenmile Groups, anaerobic respiration in microbial sediment receiving little terrigenous input

522 provided a fortuitous combination of chemistry and depositional conditions to increase $\mathrm{pH}$ and

523 precipitate authigenic Mg-silicate at near marine salinity. The subsequent burial of this material

524 would have driven a thermal transformation to kerolite and eventually to turbostratically525 disordered talc.

526 Talc is not the only product to result from unusual pore water chemistry on

527 Neoproterozoic platforms. As discussed above, the identification of saponite, an Al-bearing 528 trioctahedral smectite, suggests additional diagenetic reactions. In the absence of kinetic 
529 constraints, but instead using thermodynamic considerations based on field data, Weaver and

530 Beck (1977) suggest modern seawater need only increased $\mathrm{SiO}_{2}(\mathrm{aq})$ and/or $\mathrm{pH}$ to drive a

531 diagenetic conversion from detrital montmorillonite to saponite. Thus, the same chemical

532 conditions that led to talc precipitation were also capable of driving smectite recrystallization.

533 Bristow et al. (2009) identified saponite (and corrensite) in Member 2 of the Ediacaran

534 Doushantuo Formation and suggested a lacustrine depositional environment. Our data, however,

535 show that early diagenetic modification of Neoproterozoic seawater is also capable of producing

536 saponite. Thus, in the absence of independent sedimentological evidence of non-marine

537 deposition, saponite cannot be taken as evidence for lacustrine deposition in Neoproterozoic

538 successions. Indeed, the common occurrence of saponite in modern lacustrine settings rather than

539 marine may simply reflect decreased seawater silica levels after the radiation of siliceous

540 plankton in addition to lower modern marine $\mathrm{pH}$. This evolutionary innovation alone would have

541 been sufficient to leave modern saline lakes among the few environments able to concentrate and

542 drive saponite formation from a dioctahedral precursor.

\section{7. Conclusions}

545 Sedimentology, petrography and mineralogy all indicate that sedimentary talc reflects

546 distinct aqueous chemistry recorded on two separate Neoproterozoic carbonate platform margins.

547 Precipitation experiments with modified "Neoproterozoic-like" seawater show that elevated

$548 \mathrm{SiO}_{2}(\mathrm{aq})$, normal marine salinity and $\mathrm{Mg}^{2+}$ levels, and low $\mathrm{Al}^{3+}$ all favor talc formation. However,

549 the switch that enables talc nucleation is elevated $\mathrm{pH}$. Above $\mathrm{pH} 8.6-8.7$, the deprotonation of

$550 \mathrm{H}_{4} \mathrm{SiO}_{4}{ }^{0}$ initiates $\mathrm{Mg}$-silica complexation and nucleation, which leads to the subsequent

551 formation of a kerolite precursor composed of hydrated 2:1 layers with little to no stacking order. 
552 The progressive dehydration of this material, driven by low water activity in solution or by burial 553 diagenesis, leads to the formation of kerolite and eventually turbostratic talc.

554 Our analyses, together with other reports of sedimentary talc through this interval, 555 suggest that the later Neoproterozoic Era seawater unusually favorable for early diagenetic talc 556 precipitation. Although we argue that talc precipitation was occurring within the sediment, 557 contemporaneous seawater must have been specially poised, only requiring reasonable changes 558 to chemistry within the pore-waters. Following from this, we suggest that anaerobic respiration 559 may have provided the alkalinity pump that tipped the scales toward talc formation in soft

560 sediments. The degree to which sedimentary processes altered overlying seawater, neither of 561 which are known uniquely, hinders direct interpretation of paleo-seawater compositions and $\mathrm{pH}$. 562 Further, whether the Neoproterozoic was the first and last time talc formed with marine 563 carbonates at low temperature is unclear, but its identification of multiple continents speaks to 564 the state of the Cryogenian oceans. This study does elucidate that insight into seawater and pore565 water chemistry is clearly recorded by early diagenetic Mg-silicates. An improved understanding 566 of the kinetic and thermodynamic controls behind their formation will continue to exploit these 567 minerals as recorders of early diagenetic chemistry in modern and ancient marine and lacustrine 568 settings.

\section{Acknowledgements}

571 NJT acknowledges support from Royal Society Research Grant 2009/R2 and from Churchill 572 College, Cambridge. NJT also thanks T. Abraham, M. Zhang, R. Harrison, R. Parsons and M. 573 Walker for analytical assistance, and C. Jeans for fruitful discussions. Research by AHK and 574 DTJ supported, in part, by NASA Exobiology grant NNX07AV51G. FAM and JVS thank 
575 Charlie Roots and the Yukon Geological Survey for logistical support. The authors thank David $576 \quad$ Fike for constructive reviews.

\section{$578 \quad$ References}

579 Abbott, G., 1997, Geology of the Upper Hart River Area, Eastern Ogilvie Mountains, Yukon 580 Territory $(116 \mathrm{~A} / 10,116 \mathrm{~A} / 11)$ : Exploration and Geological Services Division, Yukon Region, Bulletin, v. 9, p. 1-76.

582 Abtahi, A., 1985, Synthesis of sepiolite at room-temperature from $\mathrm{SiO}_{2}$ and $\mathrm{MgCl}_{2}$ Solution: $583 \quad$ Clay Minerals, v. 20, p. 521-523.

584 Baronnet, A., 1992, Polytypism and stacking disorder, in Buseck, P.R., ed., Minerals and 585 reactions at the atomic scale: Transmission electron microscopy, Volume 27: Washington, DC, Mineralogical Society of America, p. 231-288.

Ben-Yaakov, S., 1973, pH buffering of pore water of recent anoxic marine sediments: Limnol. Oceanogr., v. 18, p. 86-94.

Bodine, M.W., 1983, Trioctahedral clay mineral assemblages in Paleozoic marine evaporite rocks, Sixth International Symposium on Salt, Volume 1, Salt Institute, p. 267-284.

591 Braitsch, O., 1971, Salt Deposits, Their Origin and Composition: Berlin, Springer-Verlag.

592 Brew, D.M.R., and Glasser, F.P., 2005a, The magnesia-silica gel phase in slag cements: alkali (K, 593 Cs) sorption potential of synthetic gels: Cement and Concrete Research, v. 35, p. 77-83.

594 Brew, D.R.M., and Glasser, F.P., 2005b, Synthesis and characterisation of magnesium silicate 595 hydrate gels: Cement and Concrete Research, v. 35, p. 85-98.

596 Brindley, G.W., Bish, D.L., and Wan, H.M., 1977, Nature of kerolite and its relation to talc and 597 stevensite: Mineralogical Magazine, v. 41, p. 443-452. 
Bristow, T.F., Kennedy, M.J., Derkowski, A., Droser, M.L., Jiang, G.Q., and Creaser, R.A., 2009, Mineralogical constraints on the paleoenvironments of the Ediacaran Doushantuo Formation: Proceedings of the National Academy of Sciences of the United States of America, v. 106, p. 13190-13195.

Butterfield, N.J., Knoll, A.H., and Swett, K., 1994, Paleobiology of the Neoproterozoic Svanbergfjellet Formation, Spitsbergen: Fossils and Strata, v. 34, p. 1-84.

Calvo, J.P., Blanc-Valleron, M.M., Rodriguez-Arandia, J.P., Rouchy, J.M., and Sanz, M.E., 1999, Authigenic clay minerals in continental evaporitic environments, Special Publication IAS, Volume 27, IAS, p. 129-151.

Canfield, D.E., Kristensen, E., and Thamdrup, B., 2005, Aquatic Geomicrobiology: Amsterdam, Elsevier, $636 \mathrm{p}$.

Canfield, D.E., Poulton, S.W., Knoll, A.H., Narbonne, G.M., Ross, G., Goldberg, T., and Strauss, H., 2008, Ferruginous conditions dominated later neoproterozoic deep-water chemistry: Science, v. 321, p. 949-952.

Carrado, K.A., Decarreau, A., Petit, S., Bergaya, F., and Lagaly, G., 2006, Synthetic clay minerals and purification of natural clays, in Bergaya, F., Theng, B.K.G., and Lagaly, G., eds., Handbook of Clay Science, Volume 1, Elsevier, p. 115-139.

Delacaillerie, J.B.D., Kermarec, M., and Clause, O., 1995, Si-29 NMR Observation of an amorphous magnesium-silicate formed during impregnation of silica with $\operatorname{Mg}(\mathrm{II})$ in aqueous-solution: Journal of Physical Chemistry, v. 99, p. 17273-17281.

Derry, L.A., Keto, L.S., Jacobsen, S.B., Knoll, A.H., and Swett, K., 1989, Sr isotopic variations in Upper Proterozoic carbonates from Svalbard and East Greenland: Geochimica et Cosmochimica Acta, v. 53, p. 2231-2239. 
621 Dietzel, M., 2000, Dissolution of silicates and the stability of polysilicic acid: Geochimica et 622 Cosmochimica Acta, v. 64, p. 3275-3281.

623 Evans, B.W., and Guggenheim, S., 1988, Talc, Pyrophyllite, and Related Minerals: Reviews in 624 Mineralogy, v. 19, p. 225-294.

625 Fairchild, I.J., Knoll, A.H., and Swett, K., 1991, Coastal lithofacies and biofacies associated with 626 syndepositional dolomitization and silicification (Draken Formation, Upper Riphean, 627

628 Farmer, V.C., 1974, The layer silicates, in Farmer, V.C., ed., The Infrared Spectra of Minerals: 629 Mineralogical Society Monograph: London, Mineralogical Society, p. 331-364.

630 Felmy, A.R., Cho, H., Rustad, J.R., and Mason, M.J., 2001, An aqueous thermodynamic model 631 for polymerized silica species to high ionic strength: Journal of Solution Chemistry, v. 30,

633 Fennel, K., Follows, M., and Falkowski, P.G., 2005, The co-evolution of the nitrogen, carbon 634 635 and oxygen cycles in the Proterozoic ocean: American Journal of Science, v. 305, p. 526545.

638 Frimmel, H.E., Tack, L., Basel, M.S., Nutman, A.P., and Boven, A., 2006, Provenance and 639 165-166. 
643 Gualtieri, A.F., 1999, Modelling the nature of disorder in talc by simulation of X-ray powder 644 patterns: European Journal of Mineralogy, v. 11, p. 521-532.

645 Halverson, G.P., Dudas, F.O., Maloof, A.C., and Bowring, S.A., 2007, Evolution of the Sr-87/Sr-

64686 composition of Neoproterozoic seawater: Palaeogeography Palaeoclimatology

647 Palaeoecology, v. 256, p. 103-129.

648 Iler, R.K., 1979, The Chemistry of Silica: Solubility, Polymerization, Colloid and Surface 649 Properties, and Biochemistry: New York, Wiley, 866 p.

650 Jefferson, C.W., and Parrish, R., 1989, Late Proterozoic stratigraphy, U/Pb zircon ages and rift 651 tectonics, Mackenzie Mountains, northwestern Canada: Canadian Journal of Earth Sciences, v. 26, p. 1784-1801.

Johnston, D.T., Poulton, S.W., Dehler, C., Porter, S., Husson, J., Canfield, D.E., and Knoll, A.H., 2010, An emerging picture of Neoproterozoic ocean chemistry: Insights from the Chuar Group, Grand Canyon, USA: Earth and Planetary Science Letters, v. 290, p. 64-73.

Johnston, D.T., Wolfe-Simon, F., Pearson, A., and Knoll, A.H., 2009, Anoxygenic photosynthesis modulated Proterozoic oxygen and sustained Earth's middle age: Proceedings of the National Academy of Sciences of the United States of America, v. 106, p. 16925-16929.

Jones, B.F., 1986, Clay mineral diagenesis in lacustrine sediments, in Mumpton, F.A., ed., Studies in Diagenesis, Volume 1578: USGS Bulletin, U.S. Geological Survey, p. 291-300.

Jones, B.F., and Galan, E., 1988, Sepiolite and Palygorskite: Reviews in Mineralogy, v. 19, p. 631-674.

Kah, L.C., and Bartley, J.K., 2004, Marine carbon reservoir, C-org-C-carb coupling, and the evolution of the Proterozoic carbon cycle: Geology, v. 32, p. 129-132. 
Knoll, A.H., 1984, Microbiotas of the Late Precambrian Hunnberg Formation, Nordaustlandet, Svalbard: Journal of Paleontology, v. 58, p. 131-162.

668 Knoll, A.H., Hayes, J.M., Kaufman, A.J., Swett, K., and Lambert, I.B., 1986, Secular variation in carbon isotope ratios from Upper Proterozoic successions of Svalbard and East

Knoll, A.H., and Swett, K., 1990, Carbonate deposition during the Late Proterozoic Era - an Greenland: Nature, v. 321, p. 832-838. example from Spitsbergen: American Journal of Science, v. 290A, p. 104-132.

Kogure, T., and Kameda, J., 2008, High-resolution TEM and XRD simulation of stacking disorder in $2: 1$ phyllosilicates: Zeitschrift Fur Kristallographie, v. 223, p. 69-75.

La Iglesia, A., 1978, Sintesis de la sepiolita a temperatura ambiente por precipitacion homogenea: Boletin Geologico Minero, v. 89, p. 258-265.

Lyons, T.W., and Severmann, S., 2006, A critical look at iron paleoredox proxies: New insights

Macdonald, F.A., and Roots, C.F., 2009, Upper Fifteenmile Group in the Ogilvie Mountains and from modern euxinic marine basins: Geochimica Et Cosmochimica Acta, v. 70, p. 56985722.

684 Macdonald, F.A., Schmitz, M.D., Crowley, J.L., Roots, C.F., Jones, D.S., Maloof, A.C., Strauss, J.V., Cohen, P.A., Johnston, D.T., and Schrag, D.P., 2010, Calibrating the Cryogenian: Science, v. 327, p. 1241-1243. 
Maliva, R.G., Knoll, A.H., and Simonson, B.M., 2005, Secular change in the Precambrian silica cycle: Insights from chert petrology: Geological Society of America Bulletin, v. 117, p. 835-845.

690

691

692

693

694

695

696

697

698

699

700

701

702

703

704

705

706

707

708

709

Maloof, A.C., Halverson, G.P., Kirschvink, J.L., Hoffman, P.F., and Schrag, D.P., 2004, Inertial interchange true polar wander: combined paleomagnetic, isotopic and stratigraphic evidence from the Neoproterozoic Akademikerbreen Group, Svalbard: Geological Society of America Bulletin, v. 118, p. 1099-1124.

Marumo, K., and Hattori, K.H., 1999, Seafloor hydrothermal clay alteration at Jade in the backarc Okinawa Trough: Mineralogy, geochemistry and isotope characteristics: Geochimica Et Cosmochimica Acta, v. 63, p. 2785-2804.

McCaffrey, M.A., Lazar, B., and Holland, H.D., 1987, The evaporation path of seawater and the coprecipitation of $\mathrm{Br}^{-}$and $\mathrm{K}^{+}$with halite: Journal of Sedimentary Petrology, v. 57, p. 928937.

Millot, G., and Palausi, G., 1959, Sur un talc d'origine sedimentaire: Comptes Rendus Societe Geologique Francais, p. 45-47.

Mitsuda, T., and Taguchi, H., 1977, Formation of magnesium-silicate hydrate and its crystallization to talc: Cement and Concrete Research, v. 7, p. 223-230.

Mizutani, T., Fukushima, Y., and Kamigaito, O., 1990, Mechanism of the copolymerization of silicic-acid and metal-ions in aqueous-media: Bulletin of the Chemical Society of Japan, v. 63, p. 618-619.

Mustard, P.S., and Donaldson, J.A., 1990, Paleokarst breccias, calcretes, silcretes and fault talus breccias at the base of upper Proterozoic "Windermere" strata, northern Canadian Cordillera: Journal of Sedimentary Petrology, v. 60, p. 525-539. 
710 Noack, Y., Decarreau, A., Boudzoumou, F., and Trompette, R., 1989, Low-temperature oolitic talc in Upper Proterozoic rocks, Congo: Journal of Sedimentary Petrology, v. 59, p. 717723.

713 Packter, A., 1986, Precipitation of alkaline-earth metal silicate hydrates from aqueous solution 714 Ionic equilibria, crystalline phases and precipitation mechanisms: Crystal Research and 715 Technology, v. 21, p. 575-585.

716 Poidevin, J.L., 2007, Sr-isotope stratigraphy and dating of Neoproterozoic carbonates and glacials from the northern and western parts of the Congo Craton: Comptes Rendus

Reynolds Jr., R.C., 1988, Mixed layer chlorite minerals, in Bailey, S.W., ed., Hydrous Phyllosilicates, Volume 19: Washington, DC, Mineralogical Society of America, p. 725.

721 Russell, J.D., and Fraser, A.R., 1994, Infrared methods, in Wilson, M.J., ed., Clay Mineralogy: Spectroscopic and Chemical Determinative Methods: London, Chapman and Hall, p. 11-

724 Santschi, P.H., and Schindler, P., 1974, Complex-Formation in Ternary-Systems Ca(II)- $\mathrm{H}_{4} \mathrm{SiO}_{4}-$ $725 \mathrm{H}_{2} \mathrm{O}$ and $\mathrm{Mg}(\mathrm{II})-\mathrm{H}_{4} \mathrm{SiO}_{4}-\mathrm{H}_{2} \mathrm{O}$ : Journal of the Chemical Society-Dalton Transactions, p. 726 181-184.

727 Siffert, B., and Wey, R., 1962, Synthese d'une sepiolite a temperature ordinaire: Comptes 728 Rendus de l'Academie des Sciences, v. 253, p. 142-145.

729 Stoessell, R.K., and Hay, R.L., 1978, Geochemical origin of sepiolite and kerolite at Amboseli, 730 Kenya: Contributions to Mineralogy and Petrology, v. 65, p. 255-267. 
731 Strese, H., and Hofmann, U., 1941, Synthese von Magnesiumsilikat-Gelen mit zweidimensional 732 regelmaessiger struktur: Zeitschrift fur Anorganische und Allgemeine Chemie, v. 247, p. $733 \quad 65-95$.

734 Swett, K., and Knoll, A.H., 1989, Marine pisolites from Upper Proterozoic Carbonates of East 735 Greenland and Spitsbergen: Sedimentology, v. 36, p. 75-93.

736 Takahashi, N., Tanaka, M., Satoh, T., and Endo, T., 1994, Study of synthetic clay-minerals .3. 737 Synthesis and characterization of 2-dimensional talc: Bulletin of the Chemical Society of 738 Japan, v. 67, p. 2463-2467.

739 Trompette, R., and Boudzoumou, F., 1988, Paleogeographic significance of stromatolitic 740 buildings on late Proterozoic platforms: The example of the West Congo Basin: 741 Palaeogeography Palaeoclimatology Palaeoecology, v. 48, p. 101-112.

742 Turner, E.C., and Long, D.G.F., 2008, Basin architecture and syndepositional fault activity 743 during deposition of the Neoproterozoic Mackenzie Mountains Supergroup, Northwest Territories, Canada: Canadian Journal of Earth Sciences, v. 45, p. 1159-1184.

Van Kooten, G.K., Watts, A.B., Coogan, J., Mount, V.S., Swenson, R.F., Daggett, P.H., Clough, J.G., Roberts, C.T., and Bergman, S.C., 1997, Alaska Division of Geological and Geophysical Surveys, Report of Investigations 96-6A: Fairbanks, AK.

750 Velde, B., and Meunier, A., 2008, The Origin of Clay Minerals in Soils and Weathered Rocks: $751 \quad$ Berlin, Springer-Verlag, $406 \mathrm{p}$.

752 Weaver, C.E., and Beck, K.C., 1977, Miocene of SE United-States - Model for chemical 753 sedimentation in a peri-marine environment: Sedimentary Geology, v. 17, p. 1-234. 
754 Webster, D.M., and Jones, B.F., 1994, Paleoenvironmental implications of lacustrine clay 755 minerals from the Double Lakes Formation, Southern High Plains, Texas, Sedimentology 756 and Geochemistry of Modern and Ancient Saline Lakes, Volume 50: SEPM Special 757 Publication, SEPM, p. 159-172.

758 Wei, J.X., and Chen, Y.M., 2006, Research on the cementious materials in $\mathrm{MgO}-\mathrm{SiO}_{2}-\mathrm{H}_{2} \mathrm{O}$ system at room temperature, in Tongbo, S., Rongxi, S., and Wensheng, Z., eds., Proceedings of the 6th International Symposium on Cement \& Concrete and CANMET/ACI International Symposium on Concrete Technology for Sustainable Development, Vols 1 and 2, p. 594-598.

Wollast, R., Mackenzie, F.T., and Bricker, O.P., 1968, Experimental precipitation and genesis of sepiolite at Earth-surface conditions: American Mineralogist, v. 53, p. 1645-1661.

Zhang, M., Hui, Q., Lou, X.-J., Redfern, S.A.T., Salje, E.K.H., and Tarantino, S.C., 2006, Dehydroxylation, proton migration, and structural changes in heated talc: An infrared spectroscopic study: American Mineralogist, v. 91, p. 816-825.

769 Figure captions

770 Figure 1. Bedded and nodular talc interbedded with microbialite in the Callison Lake Dolostone, 771 Ogilvie Mountains, Yukon.

772

773 Figure 2. Stratigraphic sections of the Fifteenmile and Akademikerbreen talc-bearing deposits. 774 
775 Figure 3. Void-filling talc nodules (in outcrop (A) and thin section (B) under cross-polarized

776 light) formed in dolomitic stromatolite of the Hunnberg Fm, Nordaustlandet, Svalbard. The talc

777 in (B) (orange-brown) appears penecontemporaneous with void-filling microspar cement.

779 Figure 4. XRD patterns of oriented aggregates of the $<2 \mu \mathrm{m}$ fraction extracted from talc-bearing 780 rocks. Black lines indicate scans acquired in the air-dried (Ca-saturated) state and red lines

781 indicate scans acquired in the EG-solvated state. (A) Talc from unit PF2 (U. Fifteenmile Group;

782 F927-58m) (B) Talc, saponite, and chlorite/smectite from the Hunnberg Fm (K2016). (C)

783 Saponite and illite/smectite from the Hunnberg Fm (HU1246). (D) Trioctahedral low-charge 784 corrensite from the Svanbergfjellet Fm (86-G-3).

786 Figure 5. Representative powder XRD patterns of randomly-oriented experimental precipitates 787 formed by (A) low temperature precipitation from modified seawater, (B) heating a low 788 temperature precipitate at $180^{\circ} \mathrm{C}$ for 4 weeks, (C) heating the precipitate from (B) at $400^{\circ} \mathrm{C}$ for 4 789 days. For comparison, a cleaned talc nodule from the Svanbergfjellet Fm is shown (D), 790 indicating extensive layer stacking disorder. "C" = cristobalite; " $\mathrm{D}$ " = dolomite.

792 Figure 6. FT-IR spectra of experimental Mg-silicate precipitates (black) in comparison to talc 793 collected from the Svanbergfjellet Fm (red). (A) Lattice vibration region, (B) Si-O stretching 794 region, (C) $\mathrm{H}_{2} \mathrm{O}$ and $\mathrm{CO}_{3}$ region, (D) $\mathrm{OH}$ stretching region.

796 Figure 7. Solubility diagram showing the equilibrium solubilities of crystalline talc (Jones, 797 1986), kerolite and sepiolite (Jones and Galan, 1988), "amorphous sepiolite" from Wollast et al. 
798 (1968) and the equilibrium boundary between montmorillonite and saponite from Weaver and

799 Beck (1978). Data points represent apparent solubilities calculated from solutions collected upon

800 experiment termination. Experiments that have resulted in Mg-silicate precipitate form an

801 apparent boundary approximately parallel to kerolite and/or sepioilite, but these data do not

802 represent true equilibrium conditions with respect to either of these crystalline phases. Green

803 point represents experiment at elevated $\mathrm{Mg}$ and $\mathrm{pH}_{\mathrm{f}}=8.0$ where no precipitate formed.

804

805 Figure 8. $\mathrm{SiO}_{2}(\mathrm{aq})$ loss as a function of final $\mathrm{pH}$ showing the sharp $\mathrm{pH}$ control on $\mathrm{Mg}$-silicate

806 precipitation. Process blank experiments conducted with no $\mathrm{MgCl}_{2}(\mathrm{aq})$ indicate that one

807 experiment $\left(\mathrm{pH}_{\mathrm{f}} \sim 9.2\right)$ has resulted in $\mathrm{SiO}_{2}(\mathrm{aq})$ loss that cannot be explained by experimental

808 artifacts alone and suggests the formation of a precipitate that was unable to be extracted for 809 analysis.

810

811 Figure 9. Thermodynamic calculations of $\mathrm{SiO}_{2}(\mathrm{aq})$ species distribution in "Neoproterozoic-like" 812 seawater as a function of $\mathrm{pH}$. The sharp $\mathrm{pH}$ control on the $\mathrm{MgH}_{3} \mathrm{SiO}_{4}{ }^{+}$species represents the 813 effect of $\mathrm{pH}$ on potential nucleation of Mg-silicate from seawater at elevated $\mathrm{SiO}_{2}(\mathrm{aq})$. Initial $814 \mathrm{SiO}_{2}(\mathrm{aq})=60 \mathrm{mg} / \mathrm{kg}$ and initial $\mathrm{SO}_{4 \mathrm{~T}}=2.8 \mathrm{mmol} / \mathrm{kg}$. Charge balance was satisfied by 815 readjustment of $\mathrm{CO}_{2}-\mathrm{HCO}_{3}-\mathrm{CO}_{3}$ equilibria in an open system with respect to $\mathrm{CO}_{2}(\mathrm{~g})$. All mineral 816 precipitation was suppressed. 


\section{Figure 1.}

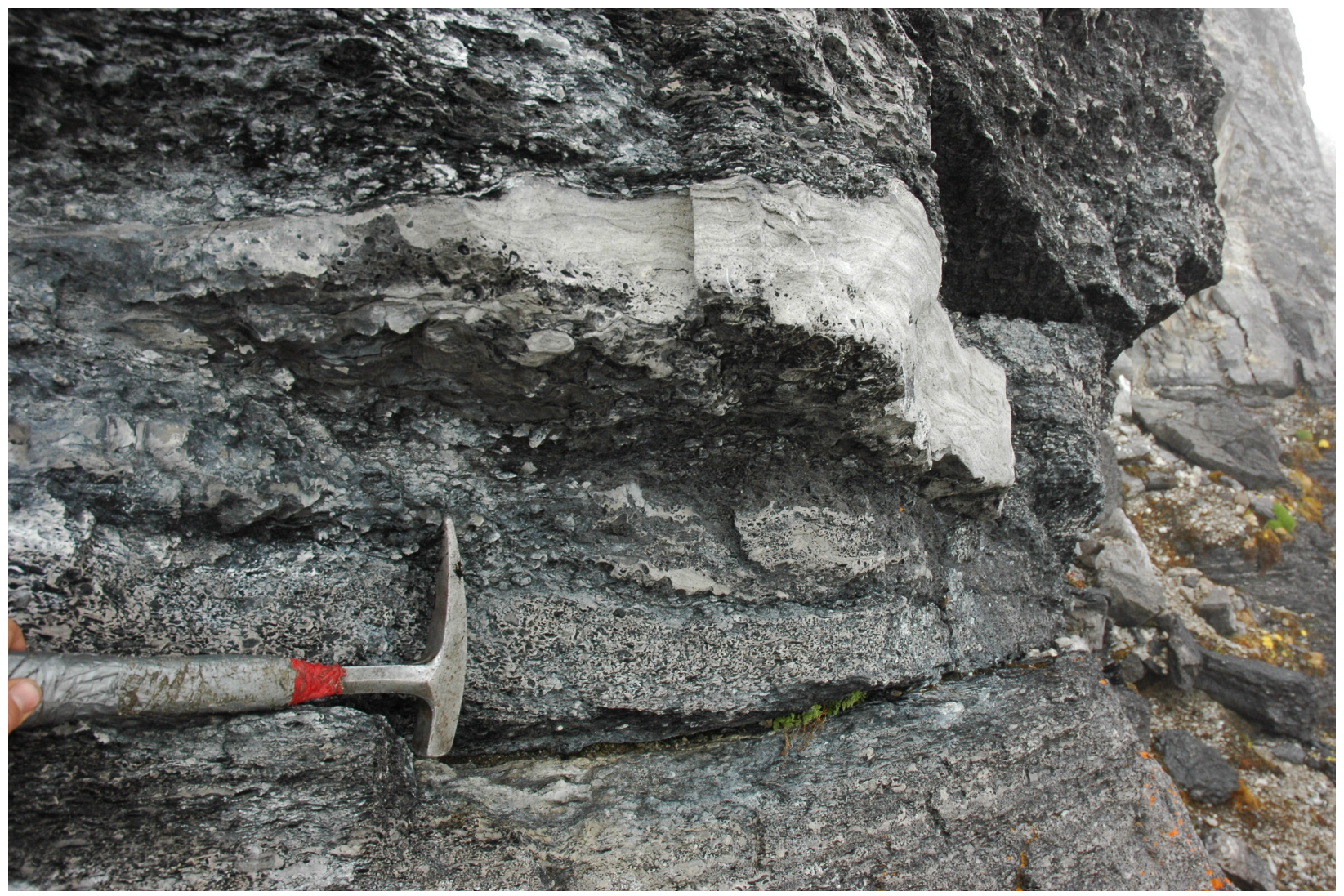


Figure 2.

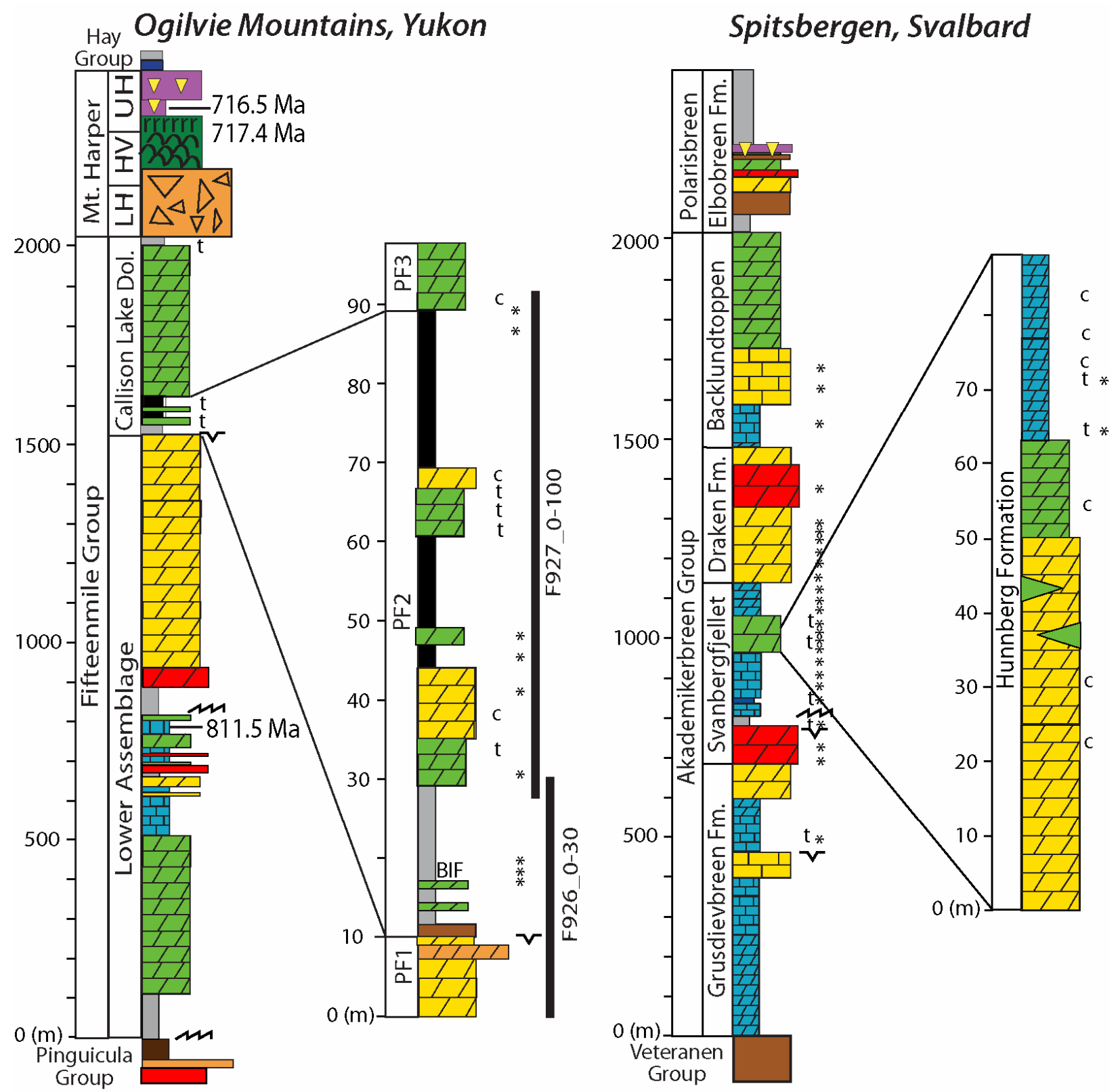

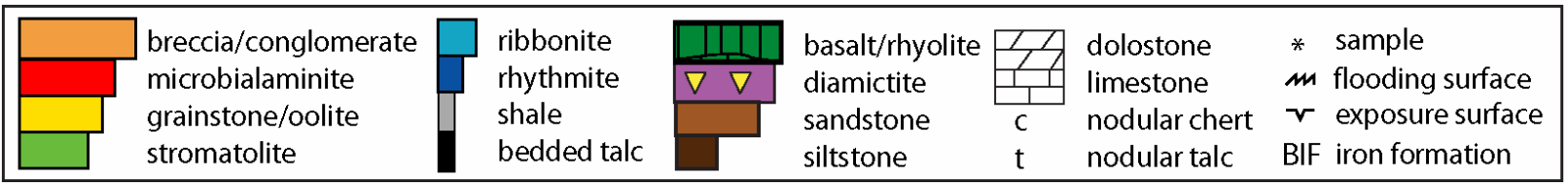


Figure 3.
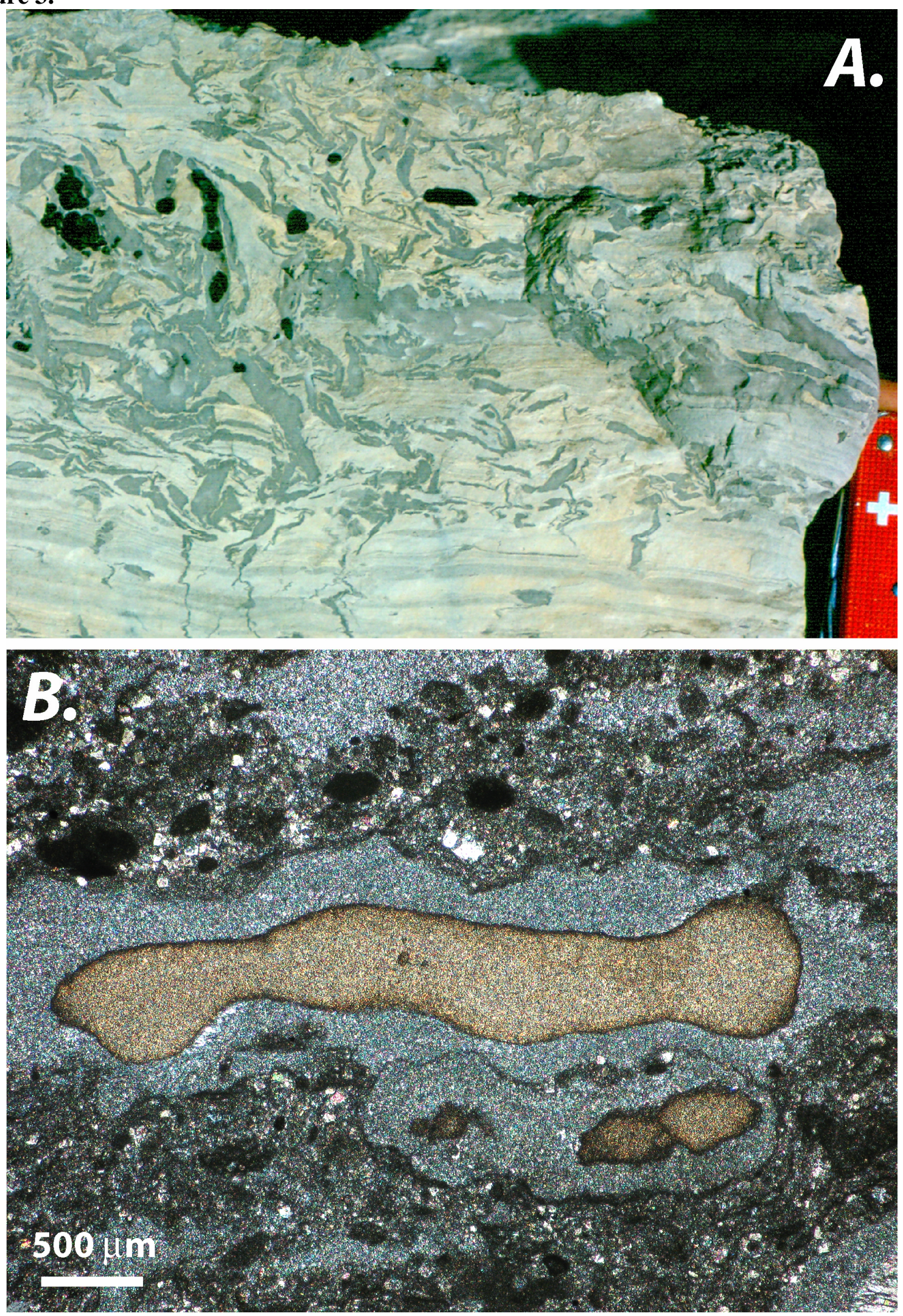
Figure 4.

Figure 5.
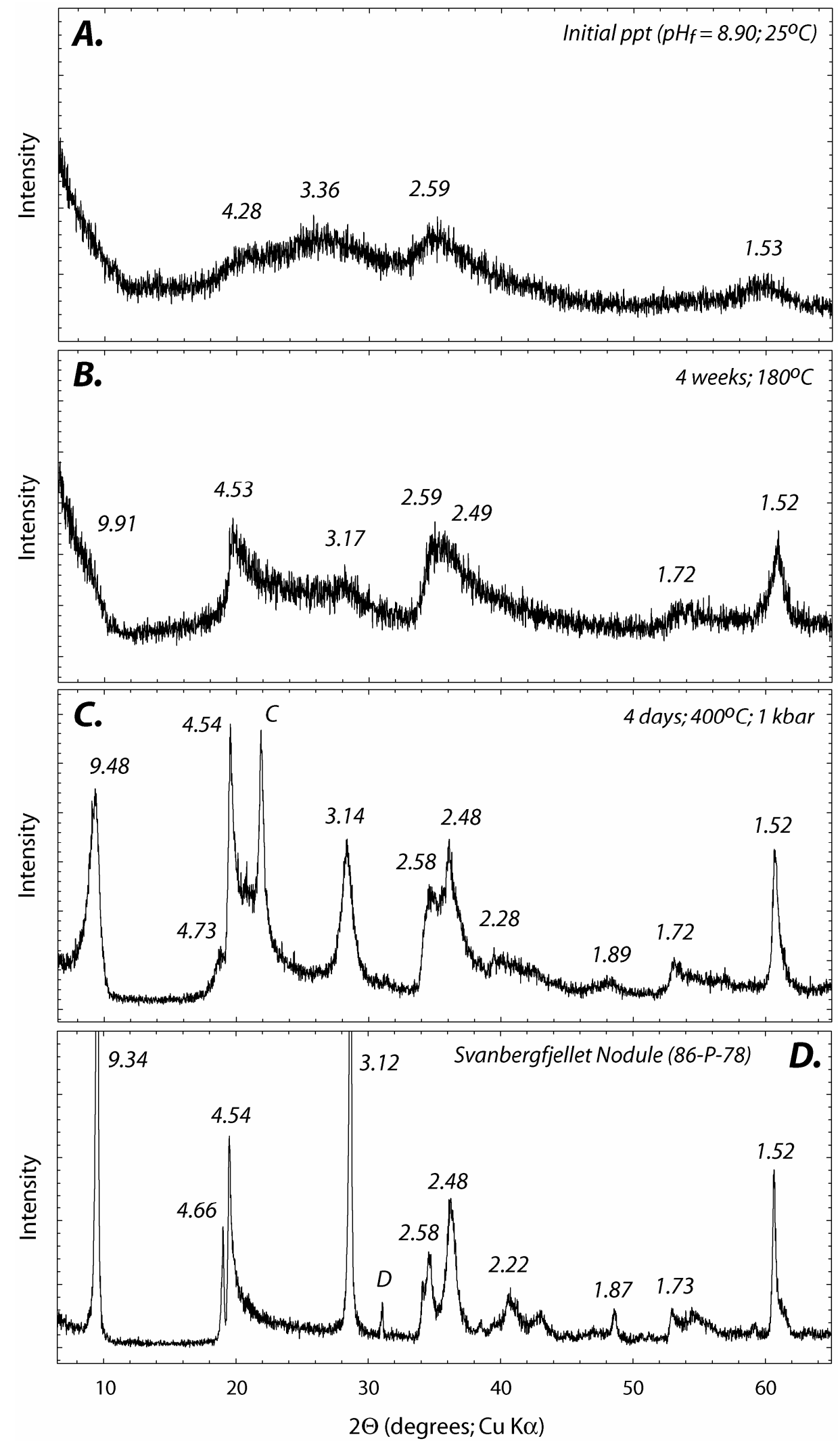
Figure 6.


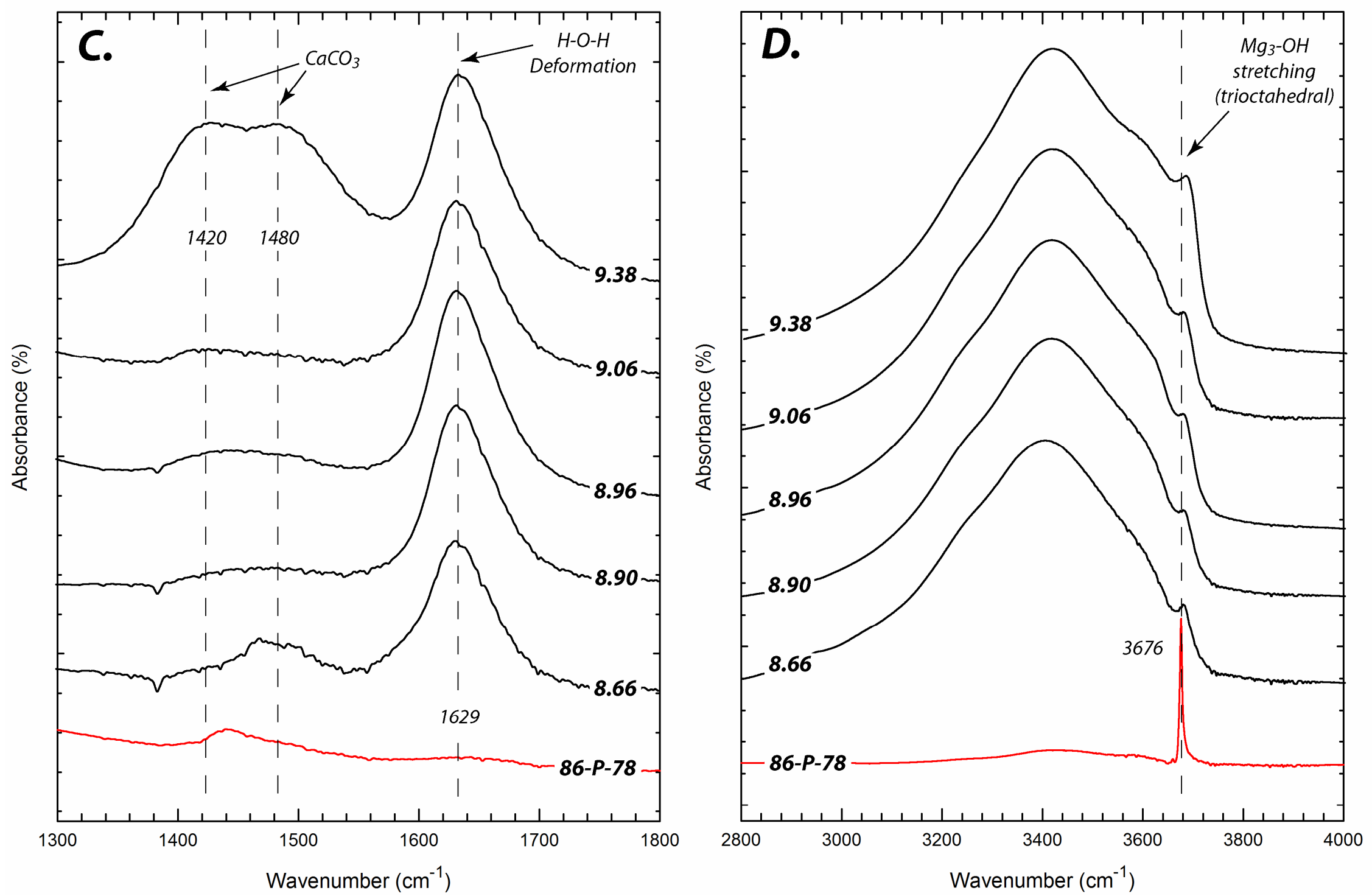
Figure 7.

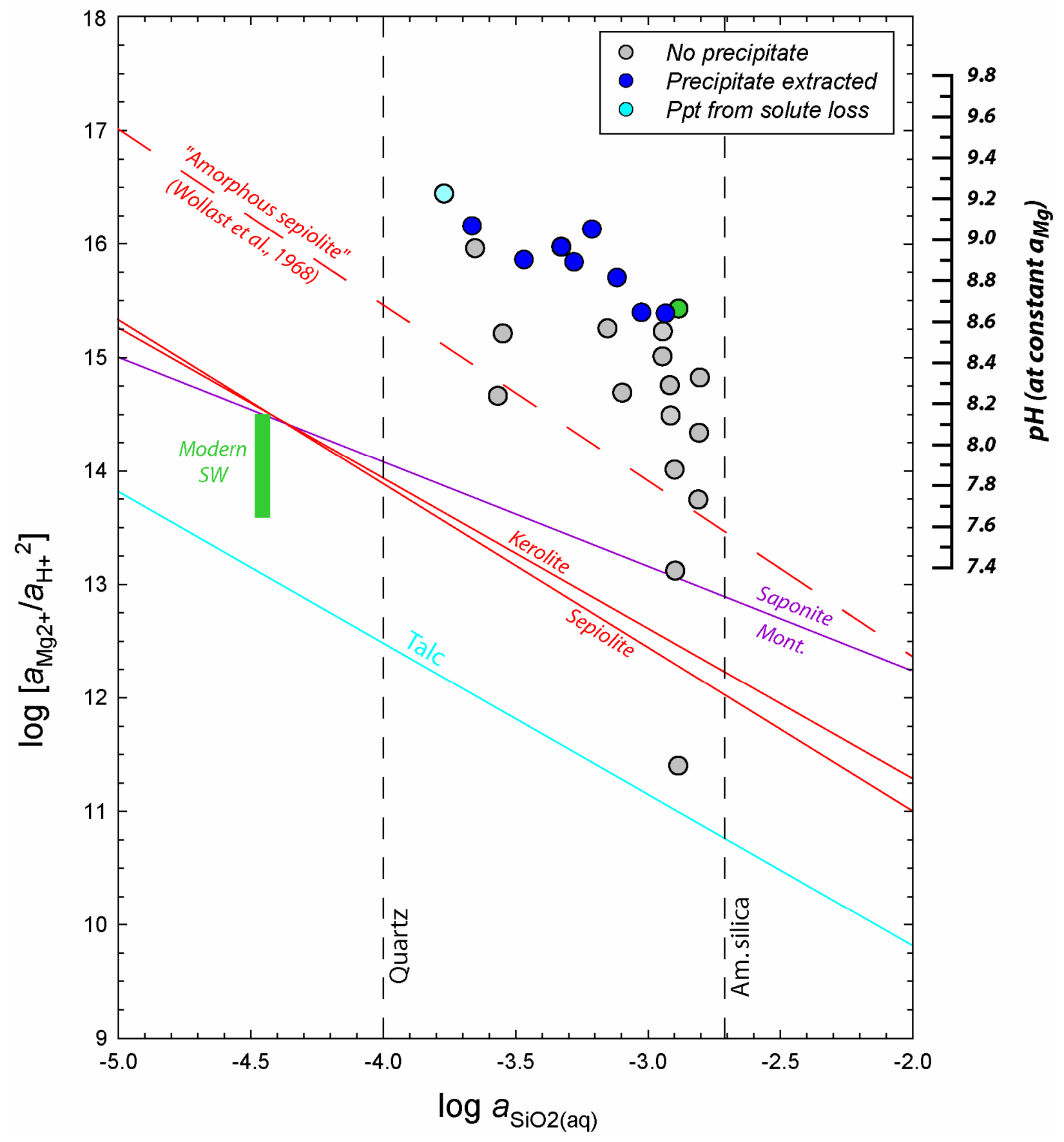


Figure 8.

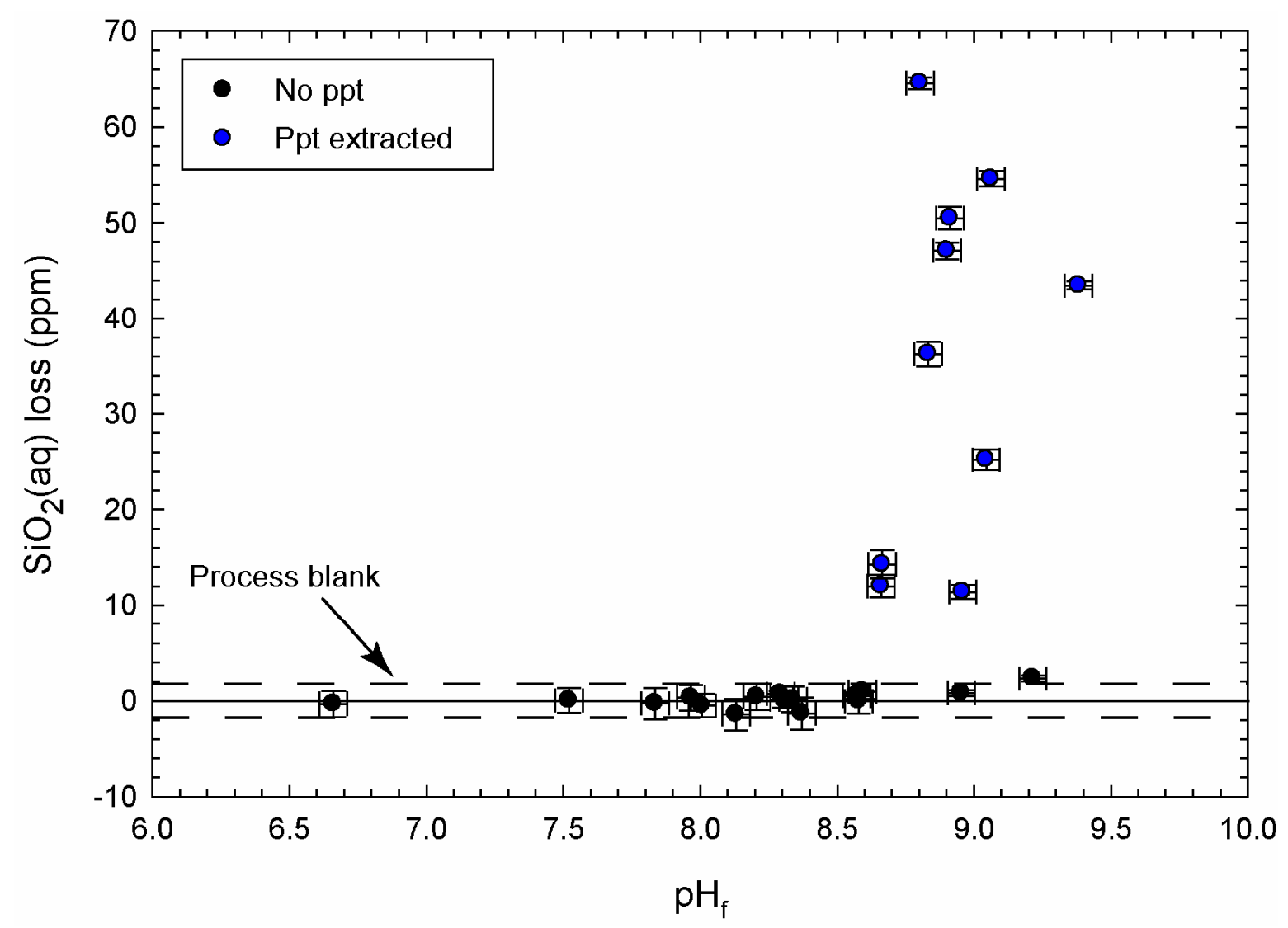


Figure 9.
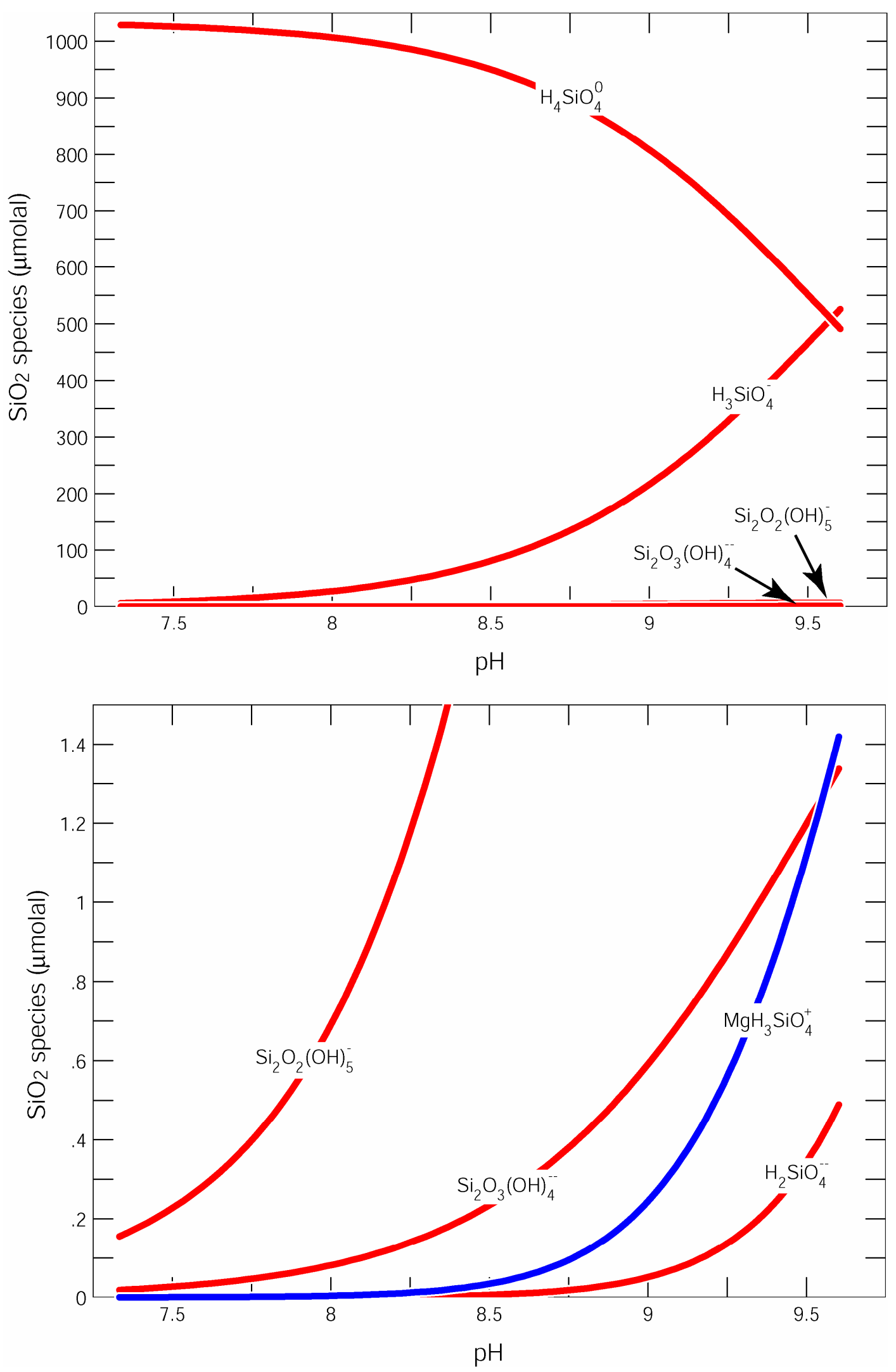
Supplemental Data File (Tosca et al., Sedimentary talc in Neoproterozoic carbonate

2 successions)

Mineralogical and geochemical analyses

expose fresh surfaces. Samples were processed with a jaw crusher and then by hand in an agate mortar and pestle. To aid carbonate dissolution, some samples were pre-ground in an agate swing mill for $<1-2$ minutes at $200 \mathrm{rpm}$. Powders were again hand ground in an agate mortar and pestle, and dissolution was performed by step-wise addition of $0.3 \mathrm{~mol} / \mathrm{kg}$ acetic acid. Solutions were monitored for effervescence to ensure that $\mathrm{pH}$ values did not drop below 4, minimizing $\mathrm{Mg}$ -

11 silicate structural modification or dissolution (Moore and Reynolds Jr., 1997; Yebra-Rodriguez et al., 2003). Samples were repeatedly rinsed and re-suspended in de-ionized water with sodium

13 phosphate as a dispersal agent and sonicated. The $<2 \mu \mathrm{m}$ fraction was then separated by gravity 14 settling and transferred to a clean glass slide in preparation for XRD using a filter-peel technique 15 (Moore and Reynolds Jr., 1997). Samples were analyzed as air-dried oriented aggregates and 16 again after ethylene glycol solvation by exposure to ethylene glycol vapor overnight at $60^{\circ} \mathrm{C}$.

X-ray diffraction of clay separates and bulk samples was performed with a Bruker D-8 Advance powder diffractometer with a $\mathrm{Cu} \mathrm{K \alpha}$ radiation at $40 \mathrm{kV}$ and $30 \mathrm{~mA}$ and also with a

19 Siemens D5000 diffractometer at $30 \mathrm{kV}$ and 20mA. Divergent slit sizes of $0.2 \mathrm{~mm}$ and receiving 20 and anti-scatter slit sizes of 0.6 and $1.0 \mathrm{~mm}$, respectively, were used. For oriented aggregates,

21 samples were analyzed at intervals of 0.03 degrees with 4-8 seconds counting per step. 22 Randomly oriented samples were analyzed from 3-65 degrees at 4 seconds per $0.02^{\circ}$ step, with $23<2 \mu \mathrm{m}$ size fractions randomly oriented and analyzed from 50-65 degrees at 30 seconds per step 24 to resolve weak 060 peaks that constrain octahedral occupancy. Electron microprobe analysis 25 was performed on polished and carbon-coated thin sections with a Cameca SX-100 electron 26 microprobe equipped with 5 wavelength dispersive spectrometers, capable of analyzing elements 27 from B to $\mathrm{U}$.

Experimental procedure

30 The source of aqueous silica used in the experiments was a $99.9 \%$ reagent-grade 31 anhydrous tetraethoxysilane (or TEOS) solution, which, upon contact with water, rapidly 
32 hydrolyzes, producing $\mathrm{SiO}_{2}(\mathrm{aq})$ and a small amount of residual ethanol. Although the hydrolysis 33 of organo-silica complexes is rapid, there is a well-documented lag period during which the 34 initially introduced $\mathrm{SiO}_{2}(\mathrm{aq})$ de-polymerizes and reaches equilibrium with the surrounding 35 solution in mostly monomeric (i.e., $\mathrm{H}_{4} \mathrm{SiO}_{4}$ ) form (Dietzel, 2000; Iler, 1979). With this in mind, 36 all $\mathrm{SiO}_{2}(\mathrm{aq})$ introduced in the experiment was given enough time to de-polymerize and 37 equilibrate in the solution before $\mathrm{Mg}$ was introduced as $\mathrm{MgCl}_{2}(\mathrm{aq})$.

Aqueous samples $(1 \mathrm{~mL})$ were periodically extracted from the experiments and immediately filtered with $0.2 \mu \mathrm{m}$ syringe-driven nylon filters, acidified and stored for analysis. Solution samples were analyzed for major element chemistry using a Varian Vista Pro simultaneous ICP-AES. Calibration was performed with eight standard solutions bracketing expected sample concentrations. In addition, two external quality control standards (matrix matched) were periodically analyzed with samples to determine external precision $(0.44 \%$ relative standard deviation for $\mathrm{Mg}$ and $\mathrm{Si}$, and $0.69 \%$ for $\mathrm{Ca}$ ) and accuracy (0.57-1.03\%).

At experiment termination, remaining solution was filtered through a $0.2 \mu \mathrm{m}$ nylon filter membrane to extract any solid precipitate that formed over the course of the incubation period.

47 Solid precipitates were dried overnight at $50^{\circ} \mathrm{C}$ and prepared as oriented aggregates and randomly oriented samples for XRD analysis. Solid samples were also analyzed by FT-IR using a Bruker IFS 66v infrared spectrometer. IR measurements were collected on $\mathrm{KBr}$ pellets with a sample: $\mathrm{KBr}$ ratio of 1:300. Measurements were collected from $350-5000 \mathrm{~cm}^{-1}$ at $1 \mathrm{~cm}^{-1}$ resolution using a DTGS detector with a $\mathrm{KBr}$ window and beamsplitter. Selected samples were prepared for TEM analysis by dispersion in ethanol and deposition on $\mathrm{Cu}$ grids.

In addition to experiments run at $25^{\circ} \mathrm{C}$, selected solid precipitates were loaded in Teflon vessels with deionized water at a solid:water ratio of 1:75. These experiments were run in hydrothermal bombs at $180 \pm 1^{\circ} \mathrm{C}$ for 2-4 weeks to simulate the effects of burial and heating on seawater precipitates over the course of burial diagenesis. Higher temperature experiments were run with precipitate and deionized water (at a solid:water ratio of 1:75) sealed in Au tubes and loaded into a cold-seal hydrothermal apparatus. Experiments were run at 3-4 days at $400^{\circ} \mathrm{C}$ and 1

59 kbar hydrostatic pressure.

60 
Thermodynamic speciation calculations for $\mathrm{SiO}_{2}(\mathrm{aq})$-bearing seawater were performed

63 with Geochemists Workbench using a Pitzer-based method for ion activity coefficient

64 calculation based on models developed by Harvie et al. (1984) and Marion and Farren (1999) for

65 major seawater components. For silica speciation in solution, we included $\mathrm{H}_{4} \mathrm{SiO}_{4}$ dissociation

66 constants from Hershey and Millero (1986) and Pitzer coefficients for $\mathrm{SiO}_{2}$ species calculated by

67 Felmy et al. (2001). We also included aqueous silica complexes from Felmy et al. (2001) and

68 Santschi and Schindler (1974). Speciation calculations discussed in the text were conducted as

69 follows: initial low-SO $\mathrm{SO}_{4}(2.8 \mathrm{mmol} / \mathrm{kg}) \mathrm{Al}$ - and $\mathrm{Fe}$-free seawater compositions were equilibrated

70 with $60 \mathrm{mg} / \mathrm{kg} \mathrm{SiO} 2(\mathrm{aq})$ and a $\mathrm{CO}_{2}$-containing atmosphere at a $\mathrm{pCO}_{2}$ to yield an initial $\mathrm{pH}$ of

$717.25\left(\log \mathrm{fCO}_{2}=-1.0\right) \cdot \mathrm{CO}_{2}$ fugacity was then decreased while maintaining equilibrium with

72 seawater by $\mathrm{pH}$ adjustment until the final seawater $\mathrm{pH}$ reached $\sim 9.7$ at a $\log \mathrm{fCO}_{2}=-4.0$.

\section{Details of clay mineral identification}

Saponite was identified by a strong basal 001 reflection in air dried oriented aggregates which shifted to $16.1 \AA$ after ethylene glycol treatment. XRD analyses of randomly oriented $<2 \mu \mathrm{m}$ powders revealed a 060 peak at $1.529 \AA$, corresponding to trioctahedral occupancy. The saponite was found only in samples from the Hunnberg Formation. One sample dominated entirely by finely laminated dolomicrite and abundant molar tooth structures yielded almost pure saponite (with a small amount of R1 illite(0.5)/smectite) after decarbonation.

Corrensite, a mixed layered regularly ordered chlorite $(0.5) /$ smectite was identified in one sample from the Svanbergfjellet Formation (86-G-3). An intense superstructure 001* reflection

83 in both the air dried and ethylene glycol-solvated states, along with a rational series of $00 l$ 84 reflections upon ethylene glycol-solvation, were sufficient to unambiguously identify corrensite 85 in this sample. The corrensite is of the trioctahedral low-charge variety, indicating that the 86 chlorite component is mixed with trioctahedral saponite.

87 Figure $4 \mathrm{~B}$ in the manuscript shows an XRD pattern of the $<2 \mu \mathrm{m}$ decarbonated residue

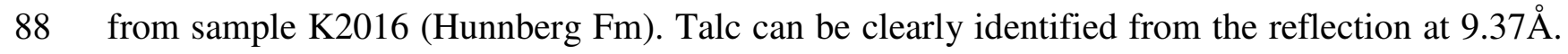
89 However, the broad peak centered at $\sim 6$ degrees $2 \Theta$ contains two reflections: $14.7 \AA$ and $13.3 \AA$ 90 in the air-dried state, and at $16.5 \AA$ and $14.9 \AA$ in the EG-solvated state. From high angle XRD 91 scans of random powders, an 060 peak is present at $1.528 \AA$, which, combined with reflections at $92 \quad 14.7$ and 16.5 $\AA$ in air-dried and EG-solvated, respectively, can be identified as saponite. The $00 l$ 
93 reflections of the additional phase are all well-matched by R1 chlorite( 0.75$) /$ smectite. Calculated

94 X-ray diffraction patterns of this phase (using the program NEWMOD; (Reynolds Jr. and

95 Reynolds, 1996)) correspond precisely with observed reflections throughout the $00 l$ series. Such

96 a mixed-layer phase is relatively uncommon in natural samples; corrensite is by far the most

97 common chlorite/smectite species, but other forms of chlorite/smectite mixed layering have been

98 reported in association with carbonate and/or evaporite deposits (e.g., (Hillier, 1993)).

References

101 Dietzel, M., 2000, Dissolution of silicates and the stability of polysilicic acid: Geochimica et Cosmochimica Acta, v. 64, p. 3275-3281.

103 Felmy, A.R., Cho, H., Rustad, J.R., and Mason, M.J., 2001, An aqueous thermodynamic model 104 for polymerized silica species to high ionic strength: Journal of Solution Chemistry, v. 30, p. 509-525.

Harvie, C.E., Moller, N., and Weare, J.H., 1984, The prediction of mineral solubilities in natural waters: The $\mathrm{Na}-\mathrm{K}-\mathrm{Mg}-\mathrm{Ca}-\mathrm{H}-\mathrm{Cl}-\mathrm{SO}_{4}-\mathrm{OH}-\mathrm{HCO}_{3}-\mathrm{CO}_{3}-\mathrm{CO}_{2}-\mathrm{H}_{2} \mathrm{O}$ system to high ionic strengths at $25^{\circ} \mathrm{C}$ : Geochimica et Cosmochimica Acta, v. 48, p. 723-751.

Hershey, J.P., and Millero, F.J., 1986, The dependence of the acidity constants of silicic acid on $\mathrm{NaCl}$ concentrations using Pitzer equations: Marine Chemistry, v. 18, p. 101-105.

Hillier, S., 1993, Origin, Diagenesis, and Mineralogy of Chlorite Minerals in Devonian Lacustrine Mudrocks, Orcadian Basin, Scotland: Clays and Clay Minerals, v. 41, p. 240259.

Iler, R.K., 1979, The Chemistry of Silica: Solubility, Polymerization, Colloid and Surface Properties, and Biochemistry: New York, Wiley, 866 p.

Marion, G.M., and Farren, R.E., 1999, Mineral solubilities in the Na-K-Mg-Ca-Cl-SO ${ }_{4}-\mathrm{H}_{2} \mathrm{O}$ system: A re-evaluation of the sulfate chemistry in the Spencer-Moller-Weare model: Geochimica et Cosmochimica Acta, v. 63, p. 1305-1318.

Moore, D.M., and Reynolds Jr., R.C., 1997, X-ray diffraction and the identification and analysis of clay minerals: New York, Oxford University Press, 378 p.

Reynolds Jr., R.C., and Reynolds, I., R.C., 1996, NEWMOD for Windows. The calculation of one dimensional X-ray diffraction patterns of mixed-layered clay minerals: Hanover, NH. 
123 Santschi, P.H., and Schindler, P., 1974, Complex-Formation in Ternary-Systems Ca(II)-H4SiO4$\mathrm{H} 2 \mathrm{O}$ and $\mathrm{Mg}(\mathrm{II})-\mathrm{H} 4 \mathrm{SIO} 4-\mathrm{H} 2 \mathrm{O}$ : Journal of the Chemical Society-Dalton Transactions, p. 181-184.

126 Yebra-Rodriguez, A., Martin-Ramos, J.D., del Rey, F., Viseras, C., and Lopez-Galindo, A., 2003, Effect of acid treatment on the structure of sepiolite: Clay Minerals, v. 38, p. 353-360.

Figure 1. Comparison of oriented $<2 \mathrm{~mm}$ fraction (EG-solvated) of sample K2016 from the

132 Hunnberg Formation, Nordaustlandet, Svalbard (A) with (B) a simulated one dimensional X-ray 133 diffraction pattern (calculated by NEWMOD) for a physical mixture of: $67 \%$ talc, $27 \%$ tri134 octahedral smectite (saponite), and 7\% R0 tri-tri chlorite 0.7/tri-smectite.

Figure 2. Transmission electron micrograph of poorly crystalline Mg-silicate precipitated at a $\mathrm{pH}$ of 8.901 (with selected area electron diffraction pattern shown in inset). Photomicrographs of experimental precipitates show a crinkly morphology at the nanometer scale, and in some regions, the development of hexagonally-shaped particles. Some regions of the precipitate exhibit observable patterns in selected area electron diffraction implying crystalline order at the nanometer scale. The smearing of diffracted spots into weak circular patterns is consistent with

142 low stacking order in the $z$ direction.

143

144

145

146

147

148 
154 Table 1. Experimental conditions

\begin{tabular}{|c|c|c|c|c|c|}
\hline Expt ID & $\mathrm{pH}_{f}$ & {$\left[\mathrm{SiO}_{2}\right]_{i}(\mathrm{ppm})$} & {$[M g]_{i}(p p m)$} & Composition & Precipitate \\
\hline MgSi_1 & 6.661 & 69.70 & 1182 & $\mathrm{SW}\left(2.8 \mathrm{mmol} / \mathrm{kg} \mathrm{SO}_{4}\right)$ & -- \\
\hline MgSi_2 & 7.521 & 68.80 & 1181 & $\mathrm{SW}\left(2.8 \mathrm{mmol} / \mathrm{kg} \mathrm{SO}_{4}\right)$ & -- \\
\hline MgSi_3 & 7.966 & 69.88 & 1178 & $\mathrm{SW}\left(2.8 \mathrm{mmol} / \mathrm{kg} \mathrm{SO}_{4}\right)$ & -- \\
\hline MgSi_4 & 8.339 & 69.17 & 1178 & $\mathrm{SW}\left(2.8 \mathrm{mmol} / \mathrm{kg} \mathrm{SO}_{4}\right)$ & -- \\
\hline MgSi_5 & 8.661 & 69.39 & 1180 & $\mathrm{SW}\left(2.8 \mathrm{mmol} / \mathrm{kg} \mathrm{SO}_{4}\right)$ & PCMS \\
\hline MgSi_6 & 8.901 & 69.39 & 1180 & $\mathrm{SW}\left(2.8 \mathrm{mmol} / \mathrm{kg} \mathrm{SO}_{4}\right)$ & PCMS \\
\hline MgSi_7 & 8.307 & 45.53 & 1165 & $\mathrm{SW}\left(2.8 \mathrm{mmol} / \mathrm{kg} \mathrm{SO}_{4}\right)$ & -- \\
\hline MgSi_8 & 8.593 & 42.87 & 1159 & $\mathrm{SW}\left(2.8 \mathrm{mmol} / \mathrm{kg} \mathrm{SO}_{4}\right)$ & -- \\
\hline MgSi_9 & 8.959 & 43.04 & 1167 & $\mathrm{SW}\left(2.8 \mathrm{mmol} / \mathrm{kg} \mathrm{SO}_{4}\right)$ & PCMS \\
\hline MgSi_10 & 9.382 & 43.81 & 1157 & $\mathrm{SW}\left(2.8 \mathrm{mmol} / \mathrm{kg} \mathrm{SO}_{4}\right)$ & Corr; pc-Talc \\
\hline MgSi_11 & 8.294 & 16.07 & 1165 & $\mathrm{SW}\left(2.8 \mathrm{mmol} / \mathrm{kg} \mathrm{SO}_{4}\right)$ & -- \\
\hline MgSi_12 & 8.570 & 17.25 & 1165 & $\mathrm{SW}\left(2.8 \mathrm{mmol} / \mathrm{kg} \mathrm{SO}_{4}\right)$ & -- \\
\hline MgSi_13 & 8.953 & 15.70 & 1165 & $\mathrm{SW}\left(2.8 \mathrm{mmol} / \mathrm{kg} \mathrm{SO}_{4}\right)$ & -- \\
\hline MgSi_14 & 9.215 & 15.50 & 1165 & $\mathrm{SW}\left(2.8 \mathrm{mmol} / \mathrm{kg} \mathrm{SO}_{4}\right)$ & -- \\
\hline MgSi_15 & 9.062 & 69.90 & 1165 & $\mathrm{SW}\left(2.8 \mathrm{mmol} / \mathrm{kg} \mathrm{SO}_{4}\right)$ & PCMS \\
\hline MgSi_16 & 7.835 & 84.70 & 1174 & $\mathrm{SW}\left(2.8 \mathrm{mmol} / \mathrm{kg} \mathrm{SO}_{4}\right)$ & -- \\
\hline MgSi_17 & 8.131 & 85.06 & 1171 & $\mathrm{SW}\left(2.8 \mathrm{mmol} / \mathrm{kg} \mathrm{SO}_{4}\right)$ & -- \\
\hline MgSi_18 & 8.371 & 85.65 & 1168 & $\mathrm{SW}\left(2.8 \mathrm{mmol} / \mathrm{kg} \mathrm{SO}_{4}\right)$ & -- \\
\hline MgSi_19 & 8.665 & 85.14 & 1195 & $\mathrm{SW}\left(2.8 \mathrm{mmol} / \mathrm{kg} \mathrm{SO}_{4}\right)$ & PCMS \\
\hline MgSi_20 & 8.833 & 85.14 & 1200 & $\mathrm{SW}\left(2.8 \mathrm{mmol} / \mathrm{kg} \mathrm{SO}_{4}\right)$ & PCMS \\
\hline MgSi_21 & 8.912 & 85.14 & 1175 & $\mathrm{SW}\left(2.8 \mathrm{mmol} / \mathrm{kg} \mathrm{SO}_{4}\right)$ & PCMS \\
\hline MgSi_22 & 8.207 & 68.92 & 1164 & $\mathrm{SW}\left(28 \mathrm{mmol} / \mathrm{kg} \mathrm{SO}_{4}\right)$ & -- \\
\hline MgSi_23 & 8.579 & 67.75 & 1165 & $\mathrm{SW}\left(28 \mathrm{mmol} / \mathrm{kg} \mathrm{SO}_{4}\right)$ & -- \\
\hline MgSi_24 & 9.044 & 68.34 & 1164 & $\mathrm{SW}\left(28 \mathrm{mmol} / \mathrm{kg} \mathrm{SO}_{4}\right)$ & PCMS \\
\hline MgSi_25 & 8.007 & 62.94 & 12900 & $\mathrm{SW}\left(2.8 \mathrm{mmol} / \mathrm{kg} \mathrm{SO}_{4}\right)$ & -- \\
\hline MgSi_26 & 8.803 & 64.88 & 12900 & $\mathrm{SW}\left(2.8 \mathrm{mmol} / \mathrm{kg} \mathrm{SO}_{4}\right)$ & PCMS \\
\hline
\end{tabular}

PCMS: Poorly crystalline Mg-silicate

pc-Talc: Poorly crystalline talc

Corr: Corrensite (trioctahedral) 
Figure 1.

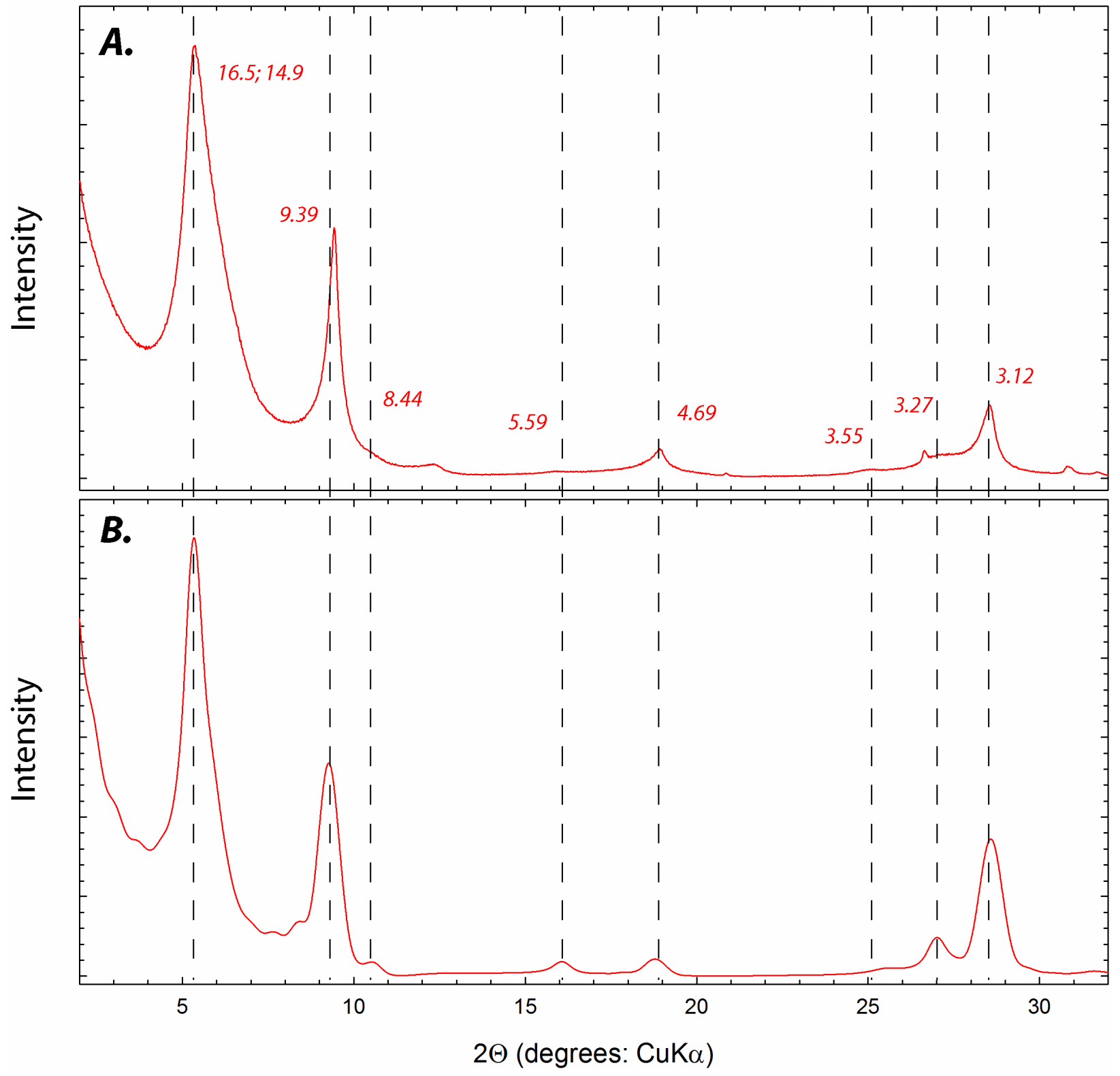

163

164

165

166

167

168

169

170

171 
172 Figure 2.


175 